Prepared in cooperation with the Washington State Department of Ecology

\title{
Approaches for Evaluating the Effects of Bivalve Filter Feeding on Nutrient Dynamics in Puget Sound, Washington
}

Scientific Investigations Report 2013-5237 



\section{Approaches for Evaluating the Effects of Bivalve Filter Feeding on Nutrient Dynamics in Puget Sound, Washington}

By Christopher P. Konrad

Prepared in cooperation with the Washington State Department of Ecology

Scientific Investigations Report 2013-5237 


\title{
U.S. Department of the Interior SALLY JEWELL, Secretary
}

\section{U.S. Geological Survey Suzette M. Kimball, Acting Director}

\author{
U.S. Geological Survey, Reston, Virginia: 2014
}

For more information on the USGS - the Federal source for science about the Earth, its natural and living resources, natural hazards, and the environment, visit http://www.usgs.gov or call 1-888-ASK-USGS.

For an overview of USGS information products, including maps, imagery, and publications, visit http://www.usgs.gov/pubprod

To order this and other USGS information products, visit http://store.usgs.gov

Any use of trade, firm, or product names is for descriptive purposes only and does not imply endorsement by the U.S. Government.

Although this information product, for the most part, is in the public domain, it also may contain copyrighted materials as noted in the text. Permission to reproduce copyrighted items must be secured from the copyright owner.

Suggested citation:

Konrad, C.P., 2014, Approaches for evaluating the effects of bivalve filter feeding on nutrient dynamics in Puget Sound, Washington: U.S. Geological Survey Scientific Investigations Report 2013-5237, 22 p., http://dx.doi.org/10.3133/sir20135237.

ISSN -2328-0328 (online) 


\section{Contents}

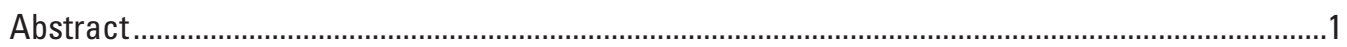

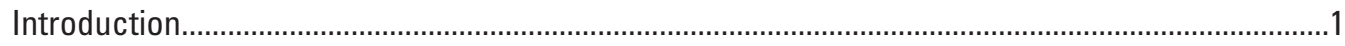

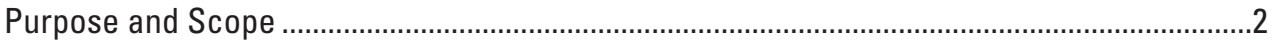

Study Area

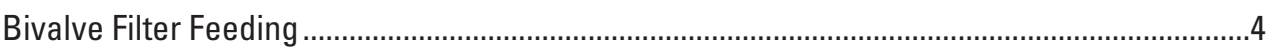

Bivalve Filter Feeding as an Ecosystem Process ..................................................................

Hierarchy of Approaches for Quantifying the Effects of Filter-Feeding Bivalves on

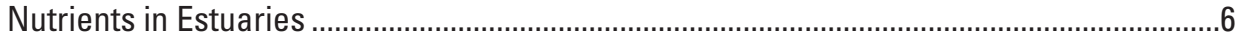

Approach 1—Nutrient Mass Balance ............................................................................

Approach 2 -Spatially Aggregated Model Based on Clearance Rate ...................................9

Approach 3-Spatially Aggregated Biophysical Indic ators .................................................11

Approach 4-Extending a Simple Biophysical Model with a Spatial Framework...................12

Approach 5-Integrating Biogeochemical Processes into a Lower Trophic Level Model....13

Approach 6-Spatially Aggregated, Bioenergetics Model with Full Trophic Dynamics........14

Approach 7-Spatially Explicit, Ecosystem Model............................................................15

A Phased Approach for Evaluating Shellfish Effects on Nutrient Dynamics...................................16

Factors to Consider in Quantifying the Effects of Shellfish on Nutrients and Associated Gaps for Application to Puget Sound...........................................................................

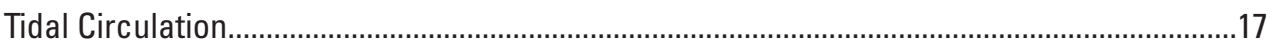

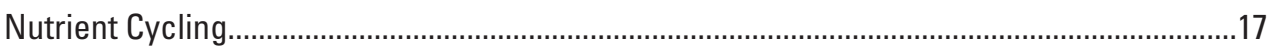

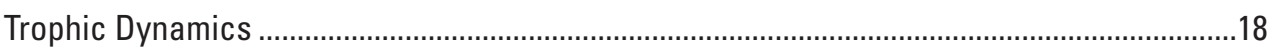

Prey Preferences and Seston Composition .......................................................................18

Seasonal Variability of Clearance Rates and Nutrient Uptake ..................................................18

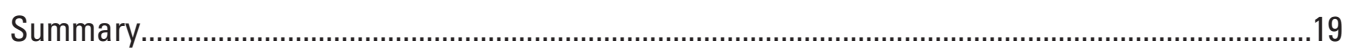

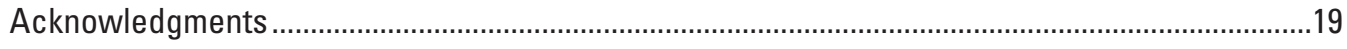

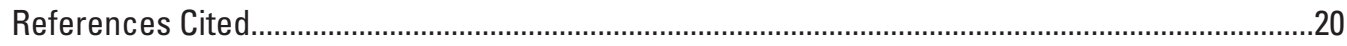




\section{Figures}

1. Map showing study area, Puget Sound, Washington

2. Biomass of harvested bivalves can be used to estimate the quantity of nutrients assimilated over their life span .......................................................................................

3. Phytoplankton removed from the water column by filter feeding is measured in terms of a clearance rate

4. Residence time, phytoplankton growth, and filter feeding constitute fundamental biophysical indicators for assessing the relative importance of filter feeding on phytoplankton

5. Spatial variation in hydrodynamics, phytoplankton growth, and filter feeding across an estuary can be addressed by using a spatially disaggregated model.

6. Nutrients released by shellfish and decomposition that contribute to the pool of nutrients in the water column available to phytoplankton

7. Filter feeders compete with other grazers for phytoplankton and feed on some (zooplankton)

\section{Table}

1. Summary of approaches for assessing the effects of bivalve filter feeding on nutrient dynamics in estuaries. 


\section{Conversion Factors and Datum}

\section{Conversion Factors}

\begin{tabular}{lcl}
\multicolumn{1}{c}{ SI to Inch/Pound } & & \\
\hline & By & To obtain \\
\hline meter $(\mathrm{m})$ & Length & foot (ft) \\
kilometer $(\mathrm{km})$ & 3.281 & mile (mi) \\
\hline & 0.6214 & \\
\hline square meter $\left(\mathrm{m}^{2}\right)$ & Area & square foot $\left(\mathrm{ft}^{2}\right)$ \\
square kilometer $\left(\mathrm{km}^{2}\right)$ & 10.76 & square mile $\left(\mathrm{mi}^{2}\right)$ \\
\hline & 0.3861 & \\
\hline liter $(\mathrm{L})$ & Volume & gallon $(\mathrm{gal})$ \\
cubic meter $\left(\mathrm{m}^{3}\right)$ & 0.2642 & cubic foot $\left(\mathrm{ft}^{3}\right)$ \\
\hline & 35.31 & \\
\hline cubic meter per second $\left(\mathrm{m}^{3} / \mathrm{s}\right)$ & Flow rate & cubic foot per second (ft $3 / \mathrm{s})$ \\
meter per second $(\mathrm{m} / \mathrm{s})$ & 35.31 & foot per second $(\mathrm{ft} / \mathrm{s})$ \\
\hline & 3.281 & \\
\hline gram $(\mathrm{g})$ & Mass & ounce, avoirdupois $(\mathrm{oz})$ \\
kilogram $(\mathrm{kg})$ & 0.03527 & pound avoirdupois $(\mathrm{lb})$ \\
\hline
\end{tabular}

Temperature in degrees Celsius $\left({ }^{\circ} \mathrm{C}\right)$ may be converted to degrees Fahrenheit $\left({ }^{\circ} \mathrm{F}\right)$ as follows:

$$
{ }^{\circ} \mathrm{F}=\left(1.8 \times{ }^{\circ} \mathrm{C}\right)+32 \text {. }
$$

Concentrations of chemical constituents in water are given either in milligrams per liter ( $\mathrm{mg} / \mathrm{L}$ ) or micrograms per liter $(\mu \mathrm{g} / \mathrm{L})$.

\section{Datum}

Horizontal coordinate information is referenced to the North American Datum of 1983 (NAD 83). 



\title{
Approaches for Evaluating the Effects of Bivalve Filter Feeding on Nutrient Dynamics in Puget Sound, Washington
}

\author{
By Christopher P. Konrad
}

\section{Abstract}

Marine bivalves such as clams, mussels, and oysters are an important component of the food web, which influence nutrient dynamics and water quality in many estuaries. The role of bivalves in nutrient dynamics and, particularly, the contribution of commercial shellfish activities, are not well understood in Puget Sound, Washington. Numerous approaches have been used in other estuaries to quantify the effects of bivalves on nutrient dynamics, ranging from simple nutrient budgeting to sophisticated numerical models that account for tidal circulation, bioenergetic fluxes through food webs, and biochemical transformations in the water column and sediment. For nutrient management in Puget Sound, it might be possible to integrate basic biophysical indicators (residence time, phytoplankton growth rates, and clearance rates of filter feeders) as a screening tool to identify places where nutrient dynamics and water quality are likely to be sensitive to shellfish density and, then, apply more sophisticated methods involving in-situ measurements and simulation models to quantify those dynamics.

\section{Introduction}

Dissolved carbon, nitrogen, and phosphorus promote the growth of phytoplankton in estuaries such as Puget Sound, Washington. Decomposition of dead phytoplankton consumes dissolved oxygen (DO) and can be the major contributor to low levels of DO (hypoxia). Hypoxia occurs in deep waters where decomposition dominates over primary production and, consequently, oxygen consumption is higher than oxygen production. Filter feeders such as oysters, mussels, and clams affect water quality in estuaries through their role in trophic webs as consumers of phytoplankton and through their influence on biogeochemical processes that regulate the storage and fluxes of nutrients between the water column and sediments.
Filter feeders consume phytoplankton and other materials suspended in the water column, digesting part of the organic material and egesting the remainder as biodeposits. Shellfish can influence nutrient fluxes through one of five main pathways: (1) regeneration of dissolved nutrients directly into the water column; (2) sequestration of nutrients bound up in bivalve tissue and shell; (3) burial of particulate in sediments; (4) regeneration of dissolved nutrients from sediments; or, (5) in the case of nitrogen, denitrification from sediments.

The benefit of filter feeders on reducing hypoxia in estuaries depends on a reduction in the flux of organic detritus to benthic sediments that creates biochemical oxygen demand (BOD) through heterotrophic respiration and decomposition of organic material. Direct manipulation of filter feeder populations through culturing and harvesting bivalves in Puget Sound, might influence nutrient availability, phytoplankton production, and, as a result, dissolved oxygen levels. Efforts in Puget Sound and other estuaries have demonstrated the potential for shellfish harvesting to remove nutrients from those systems (Rose and others, 2010; Steinberg and Hampden, 2010; Woods Hole Group, 2012).

Given the complexity of the shellfish-nutrient dynamics effect on water quality, a quantitative framework is needed to inform a broad range of management-relevant questions including:

- What quantities of nutrients do filter-feeding bivalves sequester, either in their biomass or biodeposits?

- How much do filter-feeding bivalves reduce phytoplankton biomass during spring and summer?

- How do nutrient fluxes to and from benthic sediments change in response to changes in bivalve filter feeder populations?

- What is the response of dissolved oxygen levels to shellfish in areas of Puget Sound where hypoxia occurs? 
To answer these questions, the role of shellfish must be described in terms of inputs, outputs, rate processes, and fate of nutrients in Puget Sound. The effects of shellfish on nutrient dynamics must be integrated with circulation and mixing of water, phytoplankton growth and other trophic interactions, and nutrient cycling through the water column and sediments to assess how shellfish ultimately influence water quality. Thus, the effect of shellfish on nutrients must be defined as part of a larger system and will vary with location and over time. Overall, the role of shellfish depends on how much they change the availability of nutrients through storage and regeneration.

Various approaches have been used to quantify the effects of bivalves on water quality in estuaries. This report presents a hierarchy of those approaches arrayed by an increasing breadth in type, and number of processes that are incorporated conceptually and quantitatively by each approach. The approaches have a corresponding increased level of effort for implementation. A central issue for assessing any approach is the degree to which process dynamics must be resolved given available or obtainable data to produce results with sufficient accuracy to support management actions. There is a trade-off between conceptual completeness and resource requirements: a conceptually simple approach can be implemented quickly using existing information, but will address only a narrow set of questions. A phased approach to implementation should be based on a conceptually complete framework, even if that approach has substantial information gaps. Over time, "ffilling-in" the missing information likely will be more efficient than revising the conceptual framework, which would then pose new information gaps.

\section{Purpose and Scope}

The effect of bivalves is an important issue for nutrient management intended to increase DO levels in parts of Puget Sound where hypoxia may be impairing the biological community. This report reviews current literature on the effects of bivalves on nutrient availability in estuaries with an emphasis on water quality implications of those effects. A full understanding of the effects of bivalves on water quality requires a "systems" approach that recognizes shellfish as a component in nutrient cycles that extend across estuarine systems (Strayer and others, 1999). Reducing BOD and increasing DO, however, depend not only on the uptake and sequestration of nutrients by filter feeders, but also on feedback in nutrient cycling and food webs that regulate the retention of nutrients and their availability to phytoplankton and system-scale processes, including circulation of water across an estuary. As a result, this report includes a variety of disparate approaches that may address one or more of component of nutrient cycles in estuaries. Likewise, the report has a bias in reviewing more comprehensive, but resource intensive, approaches that address a broad range of questions over large spatial and long temporal scales. Simplified methods that focuses on a narrow set of processes, locations, and times may be a more viable approach for assessing the effects of shellfish on water quality in Puget Sound, but must be designed with a specific question in mind and evaluated for the intended context. Evaluations at this level detail are beyond the scope of this report.

The literature reviewed in this report on bivalve filter feeding and water quality focuses on three primary issues: (1) carrying capacity of estuaries for bivalves, specifically in the context of aquaculture; (2) effects of invasive bivalves on estuary systems; and (3) restoration of bivalve populations. Generally, investigations of the first and second issues concern bivalve populations with high densities and water quality as an ancillary effect or an intermediary in ecosystem processes (for example, density-dependent feedback and trophic interactions). Investigations of the third issue often address water quality explicitly, but constitute a recent and relatively small part of the literature.

\section{Study Area}

Puget Sound is an estuary of the Pacific Ocean in western Washington State characterized by deep (200 m), north-south trending glacial trough fringed by shallow embayments and river deltas (fig. 1). The southern area of Puget Sound is a complex of islands and inlets that are much shallower than the main basin. Circulation is dominated by large tidal flow (mean 10,000-20,000 m³/s) compared to freshwater inflow (mean 1,000 m³/s) (Khangaonkar and others, 2012). Circulation of tidal water is limited in south Puget Sound and other embayments that are relatively long and narrow. Strong vertical gradients in biogeochemical processes (primary production concentrated in the upper photic zone and benthic decomposition of organic material) combined with differences in lateral and vertical mixing lead to local variation in temperature, nutrients, and DO. 


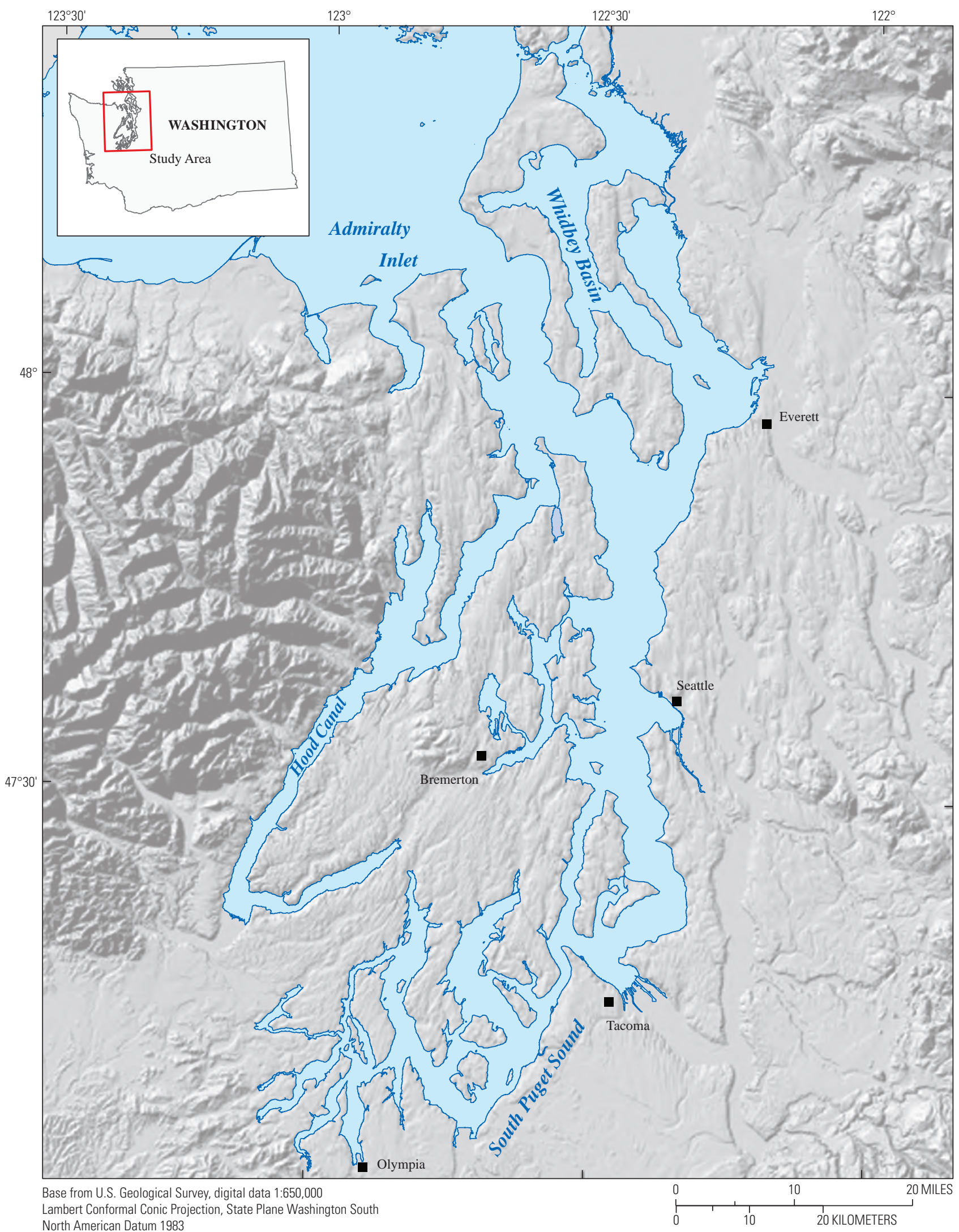

Figure 1. Study area, Puget Sound, Washington. 
Puget Sound supports a diverse estuarine community of pelagic (water column) and benthic (sediment-embedded) species. Bivalve molluscs such as mussels, clams, and oysters are ubiquitous members of inter-tidal and shallow sub-tidal communities with naturally occurring and human-cultured populations. Bivalves feed on either seston (plankton and other particulate material suspended in the water column) or benthic deposits (organic and other material on the bed of an estuary). Most bivalves harvested from Puget Sound are filter feeders, including geoducks (Panopea generosa), Pacific oyster (Crassostrea gigas), the foolish mussel (Mytilus edulis), Manila and native littleneck clams (Venerupis philippinarum and Leukoma staminea), butter clams (Saxidomus gigantea) and cockles (Clinocardium nuttallii). Some bivalves, such as the sand clam (Macoma secta), are benthic feeders.

Bivalves are part of a food web in Puget Sound that includes other filter feeders such as barnacles (for example, Balanus glandula), which are crustaceans, and aquatic invertebrates (zooplankton), primary producers (phytoplankton, benthic algae), and decomposers (bacteria and benthic invertebrates). Phytoplankton are primary producers relying on light and nutrients in the water column for growth. Zooplankton consume phytoplankton, thus, competing with bivalves, but also are consumed by bivalves.

\section{Bivalve Filter Feeding}

Bivalve filter feeders remove seston from the water column using specialized feeding organs (ctenidium). The filtered material is sorted by size, and unsuitable material is ejected as pseudofeces before digestion. The remaining material is digested and egested as feces or urine. Filter feeders also can absorb soluble nutrients (for example, free amino acids) and excrete dissolved nutrients (for example, dissolved organic carbon [DOC] and ammonia).

The direct effect of filter feeding is typically measured in terms of either a filtration rate or a clearance rate. The filtration rate is the volume of water filtered by organisms averaged over time and the area or mass of filter feeders. It does not account for the efficiency of the organisms at removing seston from the water. The clearance rate is the effective volume of water cleared of seston averaged over time, and the area or mass of filter feeders (for example, Prins and others, 1994; Petersen and others, 2004). Clearance rates are not measured directly because filter feeders do not remove all seston from the water column. Instead, clearance rates are calculated from measurements of the amount or fraction of seston removed over time.

Clearance rates can be calculated from measurements made in a laboratory, an in-situ setting using chambers or other structures to isolate shellfish beds (Prins and others, 1994; Cranford and Hill, 1999; Petersen and others, 2004; Grizzle and others, 2008; Greene and others, 2011). Clearance rates calculated in chambers typically isolate filter feeding from other transformations and changes in storage that, nonetheless, may influence the net effect on water quality. Clearance rates are not measurable at the scale of large estuaries because the effects of filter feeding cannot be partitioned out from the effects of other processes. Nonetheless, the effects of filter feeders on water quality can be observed (Smaal and others, 2001; Dame and others, 2002), and system-scale clearance rates can be estimated using models (Banas and others, 2007).

Calculated clearance rates represent a specific set of conditions, even though clearance rates are usually expressed in terms of standardized units (per area or per mass of bivalve) to facilitate comparisons. In most cases, however, clearance rates are not calculated over a range of conditions (for example, different bivalve densities) and, even when clearance rates are reported in standardized units, they should not be assumed to be "scalable" or applicable over a range of conditions (Smaal and others, 2001; Cranford and others, 2007; Grizzle and others, 2008).

Clearance rates vary with bivalve taxa and density, organism size, seston composition and concentration, and physical properties of water (Prins and others, 1998; Cranford and Hill, 1999; Ward and Schumway, 2004). Mass-specific filtration tends to be faster for bivalves of smaller size (Powell and others, 1992). Because these factors vary in space and time, a single constant clearance rate can be applied reliably across a large estuary only for periods when the factors are relatively steady. Among these factors, bivalve density and seston characteristics are a fundamental part of how clearance rates are calculated (for example, Cranford and Hill, 1999; Petersen and others, 2004). As a result, these factors should be known before applying measured clearance rates outside of the measured setting.

At low densities, filter feeding does not appreciably change the concentration of seston, and the amount of seston cleared from the water may be approximated by a constant clearance rate multiplied by filter feeder density (linear scaling). When filter feeder density is higher, water may be filtered multiple times, and there is negative feedback between the clearance rate and filter feeder density (that is, the clearance rate decreases with increasing density). Because of this feedback, seston concentration will decrease exponentially over time (that is, approaching but never reaching zero) in a closed system with no phytoplankton growth, which is the basic assumption for calculating clearance rates in closed containers (Petersen and others, 2004).

Clearance rates can be calculated for all sestonic particles, or one sestonic component (for example, phytoplankton, zooplankton, particulate organic carbon, inorganic particulates). If bivalve filter feeders were indiscriminate with no preference for certain particles, clearance rates would be equal for all components of seston 
(for example, Prins and others, 1994). Bivalves are known to have variable efficiencies and preferences when filter feeding such that clearance rates vary with particle size, concentration, and food quality (plankton species) (Prins and others, 1994; Cranford and Hill, 1999; Inoue and Yamamuro, 2000; Safi and others, 2000; Ward and Schumway, 2004; Greene and others, 2011). As a result, clearance rates calculated for one component of seston or in a specific setting may not apply to other seston components or settings with different seston composition. Likewise, clearance rates may vary depending on the type and abundance of different plankton species.

Factors other than seston composition can influence clearance rates, but in Bedford Bay and Mahone Bay, Nova Scotia, Canada, environmental factors accounted for only about 30 percent of the seasonal variance of the ingestion rates of caged mussels and scallops (Cranford and Hill, 1999). Cranford and Hill (1999) posited that seasonal ingestion rates are regulated by bivalve physiology. Bivalves feed and ingest seston selectively and modulate their digestion depending on the size and energy content of seston (Dumbauld and others, 2009) and on the metabolic demands of the bivalves. Cranford and Hill (1999) conclude that bivalve food usage is a major source of uncertainty for model accuracy.

Bivalve clearance rates have been shown to be independent of temperature after acclimatization, but may show dependence over some temperature ranges (Prins and others, 1994; Inoue and Yamamuro, 2000; Pomeroy and others, 2006; Cerco and Noel, 2007). Thatcher and Prigmore (Universal temperature coefficient for bivalve clearance rates-literature review, Department of Civil and Environmental Engineering, University of Washington, Seattle, Wash., unpub. report, December 7, 2012) suggested that measured clearance rates should be adjusted to compensate for differences between the temperature of interest and the temperature at which the rate was measured using a coefficient of approximately $1.04 \Delta \mathrm{T}$, where $\Delta \mathrm{T}$ is the temperature difference in degrees Celsius. A laboratory study of Olympia oysters (Ostrea lurida) indicated higher filtration rates (4-5 liter per hour per gram dry weight of oyster (L/hr/g dry weight) over a range of temperatures representative of Pacific Coast estuaries $\left(12-18^{\circ} \mathrm{C}\right)$ than for Crassostrea spp. (less than 3 1/hr/g dry weight) (zu Ermgassen and others, 2013).

Despite the variability in clearance rates in different shellfish populations over time, there is considerable information to constrain the possible effects of shellfish on water properties. Overall, even if estimates of filtration by a population of bivalves could be estimated only within an order of magnitude (because clearance rates vary that much across conditions, even in laboratory situations), this is still likely to help distinguish places where bivalves might affect water properties from those places where they should have small effects, even at maximum possible filtration.

\section{Bivalve Filter Feeding as an Ecosystem Process}

Bivalves influence nutrient availability in estuary systems, but their influence must be evaluated as part of a larger system where nutrients are transformed through trophic dynamics and biogeochemical processes. Bivalve filter feeding can be represented in an estuarine ecosystem by the uptake of suspended particulates and dissolved materials, and the release of biodeposits (pseudofeces and feces) and dissolved nutrients. The primary effect of filter feeding by bivalves is reduced seston particulate concentrations, including populations of plankton and bacteria, which lead to secondary effects related to changes in trophic dynamics and increased light availability to benthic primary producers. Bivalves are only effective at reducing seston concentrations, however, in parts of estuaries where water resides long enough for filter feeding to have an effect. Nutrients in biodeposits are integrated into benthic processing of sediment (for example, re-suspension of particulate forms from biodeposits, sediment diagenesis, benthic feeding by heterotrophs), whereas dissolved nutrients become available to primary producers. The full effect of bivalve filter feeding on nutrients depends on the primary effect on constituents of interest (for example, reduction of phytoplankton concentration through uptake, release of ammonia) and secondary effects mediated by trophic dynamics and biogeochemical nutrient processing in the water column and sediments.

Many recent studies have emphasized circulation and trophic dynamics over improved precision of clearance rates for quantifying the effects of bivalves on nutrients (Dame and others, 2002; Banas and others, 2007; Gibbs, 2007; Fulford and others, 2010). From an ecological perspective, the effect of bivalves on water quality depends on their clearance rate relative to circulation of water in estuary (Banas and others, 2007), but also on trophic dynamics that may create either positive or negative feedback (Prins and others, 1998). Circulation is important because it controls the volume of water that filter feeders can access (internal mixing), the advection of seston into and out of the system, and the residence time over which filter feeders can reduce seston concentrations. Trophic dynamics include feedback between bivalve filter feeding, changes in phytoplankton biomass and dissolved nutrient availability, and shifts in plankton assemblages (Smaal and others, 2001; Dumbauld and others, 2009; Fulford and others, 2010). For example, bivalve grazing can increase phytoplankton growth rates while reducing phytoplankton biomass because of increased nutrient cycling and availability in dissolved forms (Prins and others, 1998). Nutrient regeneration from shellfish beds has been shown to stimulate pelagic and benthic plankton growth (Prins and Smaal, 1994; Sandwell and others, 2009). In Lake Erie, Boegman and others (2008) view phosphorus inputs as the ultimate regulator of algae rather than zebra mussels because of efficient nutrient cycling. 
Dame and others (2002) did a manipulative experiment where they removed oysters from tidal creeks in North Inlet, South Carolina. The creeks ranged from 170 to $520 \mathrm{~m}$ in length, with mean bankfull depths of 0.4 to $0.8 \mathrm{~m}$. Seasonal variation in chlorophyll $a$, ammonium, nitrate + nitrite, and phosphorus generally was much greater than before-treatment/ after-treatment variation in these parameters. The lack of response was attributed to tidal mixing (residences times approximately 1 day) and low oyster densities (less than $30 \mathrm{~g} / \mathrm{m}^{3}$ ). Nekton (fish and mobile macroinvertebrates) generally comprised more biomass than oysters, and likely had a dominant role on the trophic dynamics of these tidal creeks. Rather than occupying competitive roles, the relation between nekton and oysters appeared to have positive feedback, with lower nekton biomass in creeks where oysters had been removed, although the mechanism remains unknown.

Bivalves can induce broader changes in estuarine food webs that affect nutrient availability. Filter feeding by non-bivalves (for example, zooplankton, polychaetes, and barnacles) represents a competing pathway that removes phytoplankton from the water column (Goldman and others, 1985; York and others, 2010). Other filter feeders such as fish can also respond to changes in food availability providing negative feedback to bivalve effects (Kimmerer, 2006).

\section{Hierarchy of Approaches for Quantifying the Effects of Filter-Feeding Bivalves on Nutrients in Estuaries}

The effects of bivalves on nutrients in estuaries depend on multiple biophysical processes that vary in space and type, and require sophisticated approaches to quantify them with precision (Cranford and others, 2007; Grant and others, 2008; Fulford and others, 2010). Different approaches can be arrayed in a hierarchy of increasing complexity that corresponds to the complexity of the questions that can be addressed. Direct effects of shellfish at short time and small spatial scales (such as changes in plankton biomass in the water column above a shellfish bed) can be addressed with simple approaches. Indirect effects involving longer time scales and larger spatial scales (such as the predicted change in biochemical oxygen demand in an embayment where shellfish biomass is manipulated through management actions) require more sophisticated approaches. As a general principle, simple approaches can be targeted to address questions with a limited scope in terms of process, time, and space. More complex approaches will be needed to address broader questions or a wider range of questions.

The different approaches contrast in terms of their resolution and the processes represented in the underlying conceptual model for the approach. A hierarchy of seven types is used here to organize the range of approaches available for assessing the effects of shellfish on nutrients and, more broadly, water quality in estuaries. The seven types are presented from basic to complex (table 1).

The spatial and temporal resolution (that is, the smallest increment that can be resolved) might be dictated by the resolution of the data used as boundary conditions, or to estimate model parameters. Alternatively, an approach might neglect or emphasize a process that only becomes important at a given spatial or temporal scale (for example, nutrient accumulation in biomass). Either the resolution or the conceptualization of processes can limit the application of an approach to address management questions. The limits of specific approaches do not preclude scaling methods such as time-series or spatially explicit modeling or embedding one approach in a broader analytical framework to address other processes. These alternatives are presented as more sophisticated approaches for ecosystem modeling. Just as the conceptualization of filter feeding-nutrient interactions and the outputs ranges among these approaches, so does the information required to implement each. 
Table 1. Summary of approaches for assessing the effects of bivalve filter feeding on nutrient dynamics in estuaries.

\begin{tabular}{|c|c|c|c|c|c|}
\hline Approach & Key data requirements & Typical temporal scale & Temporal scaling & Typical spatial resolution & Spatial scaling \\
\hline $\begin{array}{l}\text { 1. Nutrient mass } \\
\text { balance }\end{array}$ & $\begin{array}{l}\text { Mass of bivalve harvested } \\
\text { in area of interest }\end{array}$ & Life-span of bivalve & $\begin{array}{l}\text { Can be scaled down to } \\
\text { a "typical" year by } \\
\text { calculating mean annual } \\
\text { nutrient uptake }\end{array}$ & $\begin{array}{l}\text { Area of bivalve bed } \\
\text { harvested }\end{array}$ & $\begin{array}{l}\text { Can be scaled over } \\
\text { larger areas where } \\
\text { bivalve densities are } \\
\text { known and growth } \\
\text { rates are comparable }\end{array}$ \\
\hline $\begin{array}{l}\text { 2. Spatially aggregated } \\
\text { model based on } \\
\text { clearance rates }\end{array}$ & $\begin{array}{l}\text { Filter feeding rates } \\
\text { representative of area } \\
\text { of interest }\end{array}$ & $\begin{array}{l}\text { Synoptic-same as } \\
\text { period used to } \\
\text { calculate filtration } \\
\text { rate }\end{array}$ & $\begin{array}{l}\text { Can be scaled over longer } \\
\text { periods by adjusting } \\
\text { filtration rate to account } \\
\text { for temporal variability } \\
\text { in seston, temperature, } \\
\text { metabolic demand of } \\
\text { bivalve, etc. }\end{array}$ & $\begin{array}{l}\text { Same as area used to } \\
\text { calculate filtration rate }\end{array}$ & $\begin{array}{l}\text { Can be scaled over } \\
\text { larger areas by } \\
\text { adjusting filtration } \\
\text { rate for variability in } \\
\text { seston, temperature, } \\
\text { bivalve density, etc. }\end{array}$ \\
\hline $\begin{array}{l}\text { 3. Spatially aggregated } \\
\text { biophysical } \\
\text { indicators }\end{array}$ & $\begin{array}{l}\text { Rates of primary } \\
\text { production, filter } \\
\text { feeding, and mixing for } \\
\text { area of interest }\end{array}$ & $\begin{array}{l}\text { Seasonal-same as } \\
\text { period used to } \\
\text { calculate rates } \\
\text { in key data } \\
\text { requirements }\end{array}$ & $\begin{array}{l}\text { Can be scaled over time } \\
\text { by adjusting rates to } \\
\text { account for temporal } \\
\text { variability }\end{array}$ & $\begin{array}{l}\text { Area of estuary where } \\
\text { rates (key data } \\
\text { requirements) } \\
\text { are relatively } \\
\text { homogeneous }\end{array}$ & $\begin{array}{l}\text { Scaling over larger } \\
\text { area requires rates } \\
\text { appropriate for the } \\
\text { area }\end{array}$ \\
\hline $\begin{array}{l}\text { 5. Biogeochemistry in } \\
\text { a low trophic level } \\
\text { model }\end{array}$ & $\begin{array}{l}\text { Rates of primary } \\
\text { production (as } \\
\text { function of nutrient } \\
\text { concentrations) and } \\
\text { filter feeding by } \\
\text { bivalve, dissolved } \\
\text { nutrient flux from } \\
\text { bivalve (soluble } \\
\text { and solid) and from } \\
\text { sediment diagensis, } \\
\text { denitrification, rates } \\
\text { of other filter feeders } \\
\text { and associated nutrient } \\
\text { fluxes to sediment and } \\
\text { water column }\end{array}$ & $\begin{array}{l}\text { Seasonal-same as } \\
\text { period used to } \\
\text { calculate rates } \\
\text { in key data } \\
\text { requirements }\end{array}$ & $\begin{array}{l}\text { Can be scaled over time } \\
\text { by adjusting rates to } \\
\text { account for temporal } \\
\text { variability }\end{array}$ & $\begin{array}{l}\text { Area of estuary where } \\
\text { rates (key data } \\
\text { requirements) } \\
\text { are relatively } \\
\text { homogeneous }\end{array}$ & $\begin{array}{l}\text { Scaling over larger } \\
\text { areas requires } \\
\text { appropriate spatial } \\
\text { distributions of rates } \\
\text { and parameters }\end{array}$ \\
\hline $\begin{array}{l}\text { 6. Spatially } \\
\text { aggregated, } \\
\text { bioenergetics model } \\
\text { with full trophic } \\
\text { dynamics }\end{array}$ & $\begin{array}{l}\text { Spatially distributed rates } \\
\text { of primary production, } \\
\text { filter feeding, higher } \\
\text { level predation, and } \\
\text { decomposition }\end{array}$ & $\begin{array}{l}\text { Seasonal-same as } \\
\text { period used to } \\
\text { calculate rates } \\
\text { in key data } \\
\text { requirements }\end{array}$ & $\begin{array}{l}\text { Can be scaled over time } \\
\text { by adjusting rates to } \\
\text { account for temporal } \\
\text { variability }\end{array}$ & $\begin{array}{l}\text { Area of estuary where } \\
\text { rates (key data } \\
\text { requirements) } \\
\text { are relatively } \\
\text { homogeneous }\end{array}$ & $\begin{array}{l}\text { Scaling over larger } \\
\text { areas requires } \\
\text { appropriate spatial } \\
\text { distributions of rates } \\
\text { and parameters }\end{array}$ \\
\hline $\begin{array}{l}\text { 7. Spatially explicit } \\
\text { ecosystem model }\end{array}$ & $\begin{array}{l}\text { Spatially distributed } \\
\text { rates of all significant } \\
\text { biological and physical } \\
\text { processes (may be } \\
\text { a subset of all those } \\
\text { listed for other } \\
\text { approaches) }\end{array}$ & $\begin{array}{l}\text { Seasonal-same as } \\
\text { period used to } \\
\text { calculate rates } \\
\text { in key data } \\
\text { requirements }\end{array}$ & $\begin{array}{l}\text { Can be scaled over time } \\
\text { by adjusting rates to } \\
\text { account for temporal } \\
\text { variability }\end{array}$ & $\begin{array}{l}\text { Area of estuary where } \\
\text { rates (key data } \\
\text { requirements) } \\
\text { are relatively } \\
\text { homogeneous }\end{array}$ & $\begin{array}{l}\text { Scaling over larger } \\
\text { areas requires } \\
\text { appropriate spatial } \\
\text { distributions of rates } \\
\text { and parameters }\end{array}$ \\
\hline
\end{tabular}




\section{Approach 1-Nutrient Mass Balance}

Nutrient mass balances represent the most simple and direct approach for quantifying the effects of bivalves on nutrients. This approach requires a "control" volume (typically a shellfish bed), and either measurements of nutrients removal represented by shellfish harvest (fig. 2).

Dame and others (1989) examined exchanges of nutrients during a year across an oyster reef in Bly Creek, South Carolina. They calculated net retention of 189 grams of nitrogen per square meter per year $\left(\mathrm{g} \mathrm{N} \mathrm{m}^{2} \mathrm{yr}^{-1}\right)$, 1,200 grams of carbon per square meter per year $\left(\mathrm{g} \mathrm{C} \mathrm{m}^{2} \mathrm{yr}^{-1}\right)$, and 98 grams of phosphorus per square meter per year ( $\mathrm{g} \mathrm{P} \mathrm{m}^{2} \mathrm{yr}^{-1}$ ), though retention of $\mathrm{P}$ was the only result of statistical significance. Oysters facilitated nutrient cycling by taking up particulate forms of nutrients and releasing a substantial fraction in dissolved forms including $\mathrm{NH}_{4}$ (125 $\mathrm{g} \mathrm{N} \mathrm{m}^{2} \mathrm{yr}^{-1}$, or 66 percent of gross nitrogen uptake), DOC (2,590 g C m $\mathrm{yr}^{-1}$ or 63 percent of gross carbon uptake), and $\mathrm{PO}_{4}\left(7.7 \mathrm{~g} \mathrm{P} \mathrm{m}^{2} \mathrm{yr}^{-1}\right.$ or 8 percent of gross phosphorus uptake). A pilot study in Long Island Sound, New York, was started in 2011 to assess the feasibility of extracting nutrients using a mussel raft), but has not yet reported results (Long Island Sound Study, 2013). Miller and Wands (2009) estimated a maximum potential increase in benthic dissolved oxygen of $1.5 \mathrm{mg} / \mathrm{L}$ in the western part of Long Island Sound from shellfish and macroalgae harvest. Steinberg and Hampden
(2010) calculated removal of 11.7 million tons of nitrogen per year (MT N yr-1) from Oakland Bay, Washington, based on a nitrogen concentration of 1 percent of wet bivalve weight.

Estimates of nutrient removal from harvested biomass are likely feasible for other embayments in Puget Sound, but do not resolve the question of when the nutrients were sequestered or the indirect effects on water quality. Given the seasonal variability in hypoxia, and the potential efficiency of nutrient cycling, it is not clear that estimates of nutrients removed by shellfish harvest will address the broader water quality effects. Moreover, nutrient budgeting based on shellfish harvest alone does not account for changes in nutrient retention that can result from bivalve filter feeding. For example, Cranford and others (2007) concluded that bivalves increase retention of nutrients in Tracadie Bay, Prince Edward Island, Canada that they are delivered by freshwater inflows and otherwise would have been flushed out of the system by tidal circulation.

Nonetheless, shellfish harvest can provide a simple approach for estimating the nutrients removed by bivalves that might be useful in a broader nutrient budgeting framework. Annual rates of nutrient removal can be calculated from shellfish harvest, assuming aquaculture maintains shellfish beds with widely distributed age classes at less than the carrying capacity of the system; however, harvest data cannot be used alone to resolve seasonal variability in nutrient uptake.

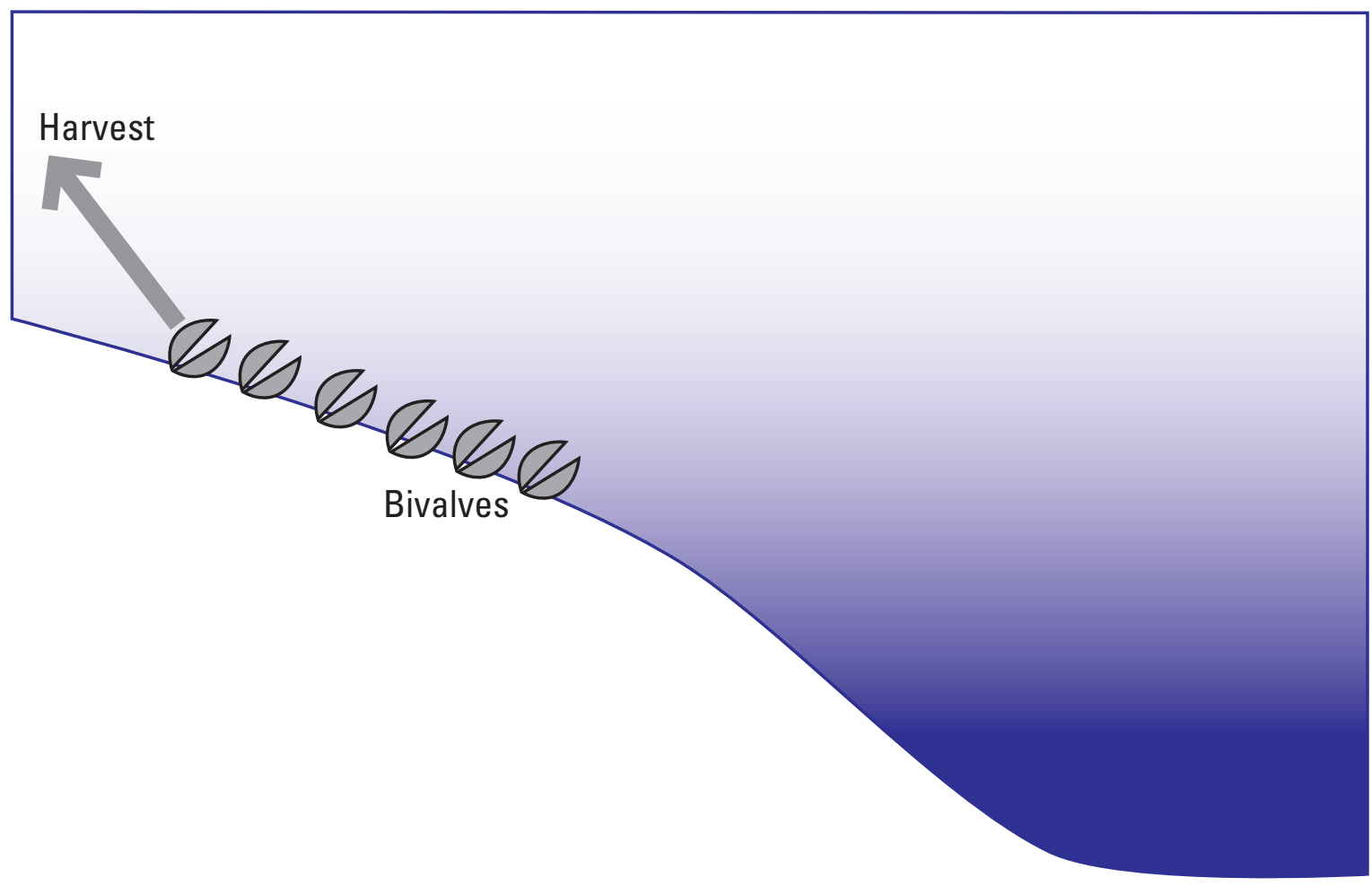

Figure 2. Biomass of harvested bivalves can be used to estimate the quantity of nutrients assimilated over their life span. Shading indicates limited light availability for phytoplankton. 
Nutrient mass balance is not a feasible approach for a broader nutrient budgeting framework because of difficulties in measuring and calculating nutrient fluxes, changes in storage, and transformations for a large area of an estuary during periods of interest. Dame and others (1989) measured particulate and dissolved nutrient fluxes into and out of a tunnel placed over an $8 \mathrm{~m}^{2}$ area of the Bly Creek oyster reef in South Carolina at different points in the tidal cycle, every 10 days for a year. The measurements were used to develop a regression model to estimate net annual processing of carbon, nitrogen, and phosphorus. Any model developed from plot-scale data, however, would likely require modification to be scaled up accurately to large areas of the estuary. Such a model would require demonstration at the scale of interest, for example, in an embayment where nutrient fluxes could be measured.

Nutrient mass balances may be useful in small, semienclosed water bodies where nutrient fluxes from the watershed, estuarine circulation, and sediment burial are well known. This approach would require harvest amounts and nitrogen content as well as the other fluxes. The approach also could be used as a screening tool to identify regions within Puget Sound where the ratio of current or potential harvested nitrogen is the highest around Puget Sound.

\section{Approach 2-Spatially Aggregated Model Based on Clearance Rate}

Bivalve filter feeders directly affect water quality by reducing seston concentration (fig. 3 ). The amount of seston removed per unit time is referred to as the "clearance rate." In a basic conceptual model for filter feeding, the clearance rate is change in seston concentration in a parcel of water over time accounting for net advection (inflow or outflow) of seston into the parcel and phytoplankton growth.

This conceptual model represents the analytical framework for calculating clearance rates in controlled chambers by measuring either net advection of seston or seston concentration changes (Prins and others, 1994; Petersen and others, 2004; Greene and others, 2011) or in-situ (Dame and others, 1989; Grizzle and others, 2008). The calculations provide a time-average clearance rate for a "parcel" of water where dispersion maintains a relatively uniform concentration of phytoplankton throughout the parcel-typical vertical scale of meters and horizontal scale up to tens of meters. Because clearance rates are averages in time and space, they must be calculated for the time-scale and system extent of interest, or they must be adjusted to account for spatial and temporal variability. The factors that cause variability in clearance rates include seston composition and concentration, which in turn can be regulated by filter feeder density.

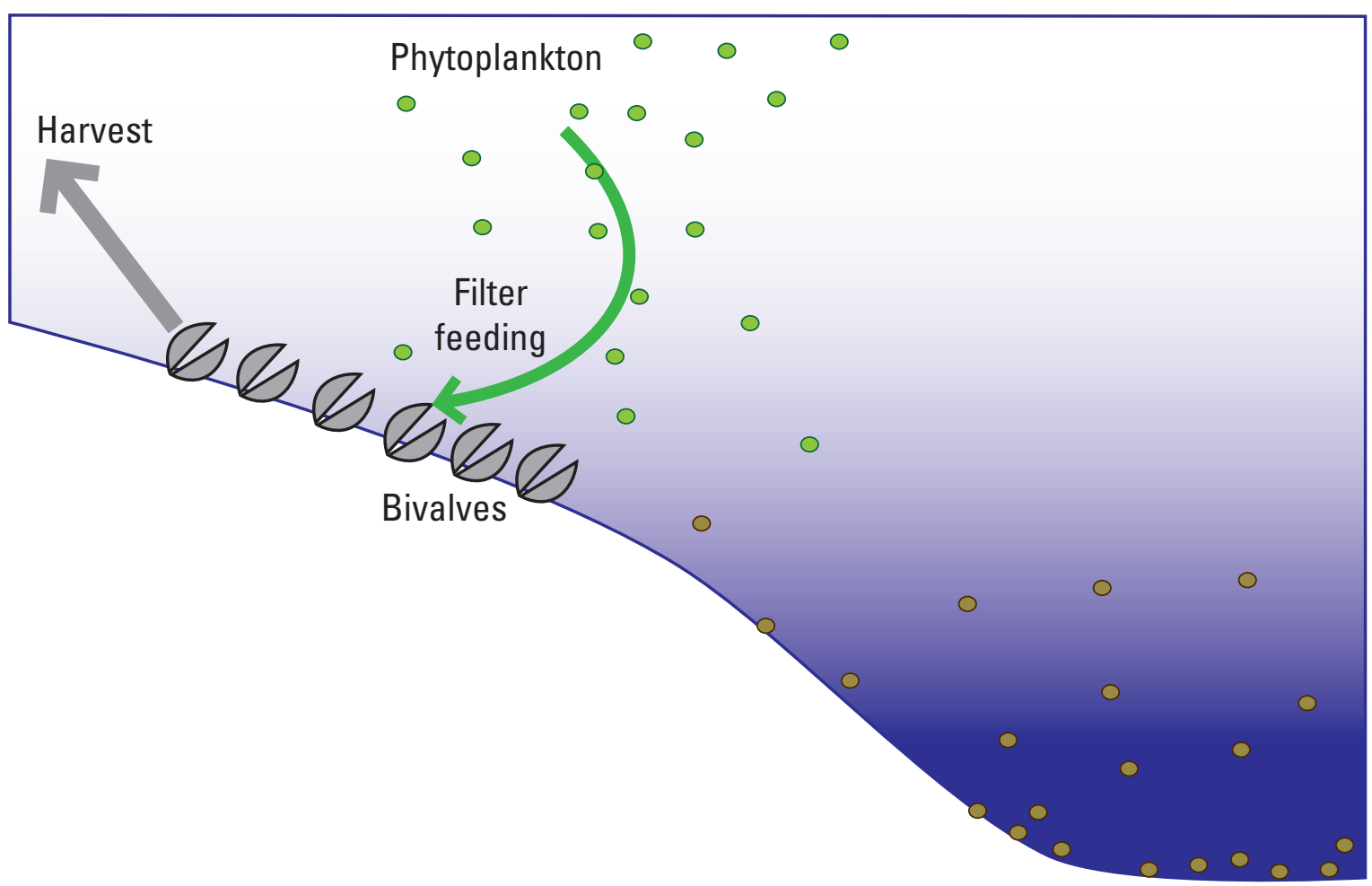

Figure 3. Phytoplankton removed from the water column by filter feeding is measured in terms of a clearance rate. Shading indicates limited light availability for phytoplankton. 
Clearance rates cannot be extrapolated over time indefinitely in closed systems because of their dependency on seston concentration and growth of phytoplankton. As filter feeders begin to compete for food resources, the system-average clearance rate or, alternatively, the efficiency of filtration (for example, the ratio of the volume of water cleared to the volume of water filtered) will decrease. Smaal and others (2001) investigated the effects of a storm surge barrier constructed across the Oosterschelde estuary, Netherlands on trophic dynamics and mussel production. The barrier increased residence time in much of the estuary from 5-50 days to 10-150 days. Although seston concentrations including phytoplankton decreased, phytoplankton turnover rates have doubled from $0.3-0.4$ times per day to $0.6-0.8$ times per day. Primary production is largely unchanged. By filtering phytoplankton and regenerating nutrients, bivalves stimulate phytoplankton growth providing positive feedback on their food source.

Clearance rates must be representative of conditions within an area of interest, including bivalve species, size, and density and seston concentrations and composition, particularly with respect to the phytoplankton assemblage. Variability in these factors between the area of interest and area where clearance rates were measured introduces a significant source of uncertainty when extrapolating measured clearance rates over time, or to locations other than those where the rates were measured. These factors are neglected when using a linear relation (that is, a constant clearance rate) to quantify the sensitivity of nutrient uptake to filter feeder abundance. As a result, local, in-situ measurements are the preferred basis for scaling clearance rates to a larger system (Dame and others, 1989; Prins and others, 1994; Cranford and Hill, 1999; Grizzle and others, 2008).

Clearance rates have been scaled up using simple linear extrapolation based on filter-feeder densities to estimate the effect of filter-feeding bivalves on plankton in San Francisco Bay, California (Greene and others, 2011). Linear extrapolation of clearance rates to an entire estuary or large areas therefore overestimates the effect of filter feeders where incomplete mixing prevents filter feeders from accessing phytoplankton contained in the estuary, which violates the dispersion assumption. The dispersion assumption is violated in any situation where the water subject to filtration by shellfish is not fully mixed within the parcel of water containing the plankton. Thus, linear extrapolation of clearance rates must be limited to embayments that are internally well mixed, but relatively isolated from tidal exchange (long residence time). Linear scaling of clearance rates does not account for the effect of changes in phytoplankton concentration on BOD or nutrient concentrations, the fate of biodeposits and nutrients excreted by bivalves, or feedback between phytoplankton concentrations and consumption by other grazers.

Clearance rate also can be estimated using biomass accumulation of a bivalve population. This accumulation must be supported through energy acquisition, and bioenergetics models to assist this back-calculation are well developed for a major aquaculture species in Puget Sound, Pacific oysters (Crassostrea gigas) (Alunno-Bruscia and others, 2011).

Ferreira and others (2007) developed the Farm Aquaculture Resource Management (FARM) model to optimize seeding and harvesting in shellfish aquacultural operations and to evaluate effects on eutrophication. The model integrates nutrient removal from shellfish harvest into a broader water-quality framework at the scale of a shellfish bed. The direct effects of shellfish filter feeding are represented by a reduction in concentrations of chlorophyll and particulate organic matter for one-dimension, horizontal flow across the bed. Effects on eutrophication are then assessed separately using the Assessment of Estuarine Trophic Status model (Bricker and others, 2003) adapted to local scale. The model can be run at daily time step, but is relatively insensitive to daily variation in temperature and seston during validation and, as a result, was run using time-constant inputs (Ferreira and others, 2007). In 2012, Pacific Shellfish Institute (2013) initiated a project to apply FARM to shellfish farms in South Puget Sound. The results of that project, which are anticipated in 2014, will be useful for evaluating the utility and viability of applying FARM to Puget Sound.

Although this approach of using spatially-aggregated clearance rates may be useful in semi-enclosed water bodies or regions where net circulation is well known, this review did not identify clearance rates that had been calculated for any parts of Puget Sound (for example, Dumbauld and others, 2009). The basic information required for estimating in-situ clearance rates include estimates of number or density of shellfish and the difference in seston concentration across a shellfish bed that represents the reduction from shellfish feeding. The bed must be large enough to have a measurable effect on seston concentration, but also must have welldefined boundaries that permit flux measurements into and out of the area. Clearance rates estimated from system-scale measurements rather than chambers integrate a broader range of processes that determine the net effect of bivalves on seston concentration (for example, phytoplankton growth in response to nutrients released by bivalves). Nonetheless, linear extrapolation of measured rates to account for changes in shellfish abundance does not account for density dependence, which is known to reduce the system-average clearance rate (Banas and others, 2007). 


\section{Approach 3-Spatially Aggregated Biophysical Indicators}

An approach that is slightly more sophisticated than relying on measured bivalve clearance rates is one that integrates those rates with information about estuary circulation and phytoplankton growth (fig. 4). Filter feeder clearance time (the estuary volume divided by clearance rate) is compared to water residence time and to phytoplankton production time (the time required to replace or double the biomass of phytoplankton to evaluate the effect of filter feeding bivalves on phytoplankton biomass for an entire estuary).

Rather than estimating the quantitative effect of bivalves, Dame and Prins (1998) used bivariate plots to assess the strength of filter feeding relative to circulation and phytoplankton production on phytoplankton biomass. Dame and Prins (1998) presented a graphical analysis to compare the productivity and sustainability of bivalve populations in 11 estuaries. They note, however, that this approach is limited by its lack of temporal and spatial resolution and is probably best as a screening tool for more detailed analysis.

Gibbs (2007) followed this approach to develop four indicators of aquaculture sustainability. In addition to indicators of clearance rate relative to phytoplankton growth and tidal flushing, he introduced an indicator of "filtration pressure," which is annual yield of bivalves divided by phytoplankton production and "depletion footprint," which is the cumulative distribution of chlorophyll $a$ in a region of an estuary used for aquaculture. The depletion footprint requires a large set of high-resolution water-quality samples to identify localized areas where phytoplankton have been depleted. The values of individual samples are aggregated into a single distribution where the indicator is the proportion of the region that exceeds some level of depletion.

Approach 3 may be useful for screening areas of Puget Sound where tidal circulation can be described in terms of homogeneous residence times, and where average phytoplankton growth rates and filter feeder clearance rates can be estimated from other studies (for example, Winter and others, 1975; Powell and others, 1992; Banas and others, 2007). Given the capability of calculating local residence times from hydrodynamic models for Puget Sound (for example, Babson and others, 2006; Roberts and others, 2009; Khangaonkar and others, 2012), the biophysical-indicator approach could be applied with a much finer resolution than the entire estuary. For example, Bricker and others (2007) estimated a 1 day residence time in Willapa Bay, whereas Banas and others (2007) estimated a wide range of residence times that extend to as many as 50 days. For nutrient management applications, the result would be the relative affect of bivalve filter feeders on phytoplankton biomass in parts of the Puget Sound with distinct residence times, phytoplankton growth rates, and (or) clearance rates. Although

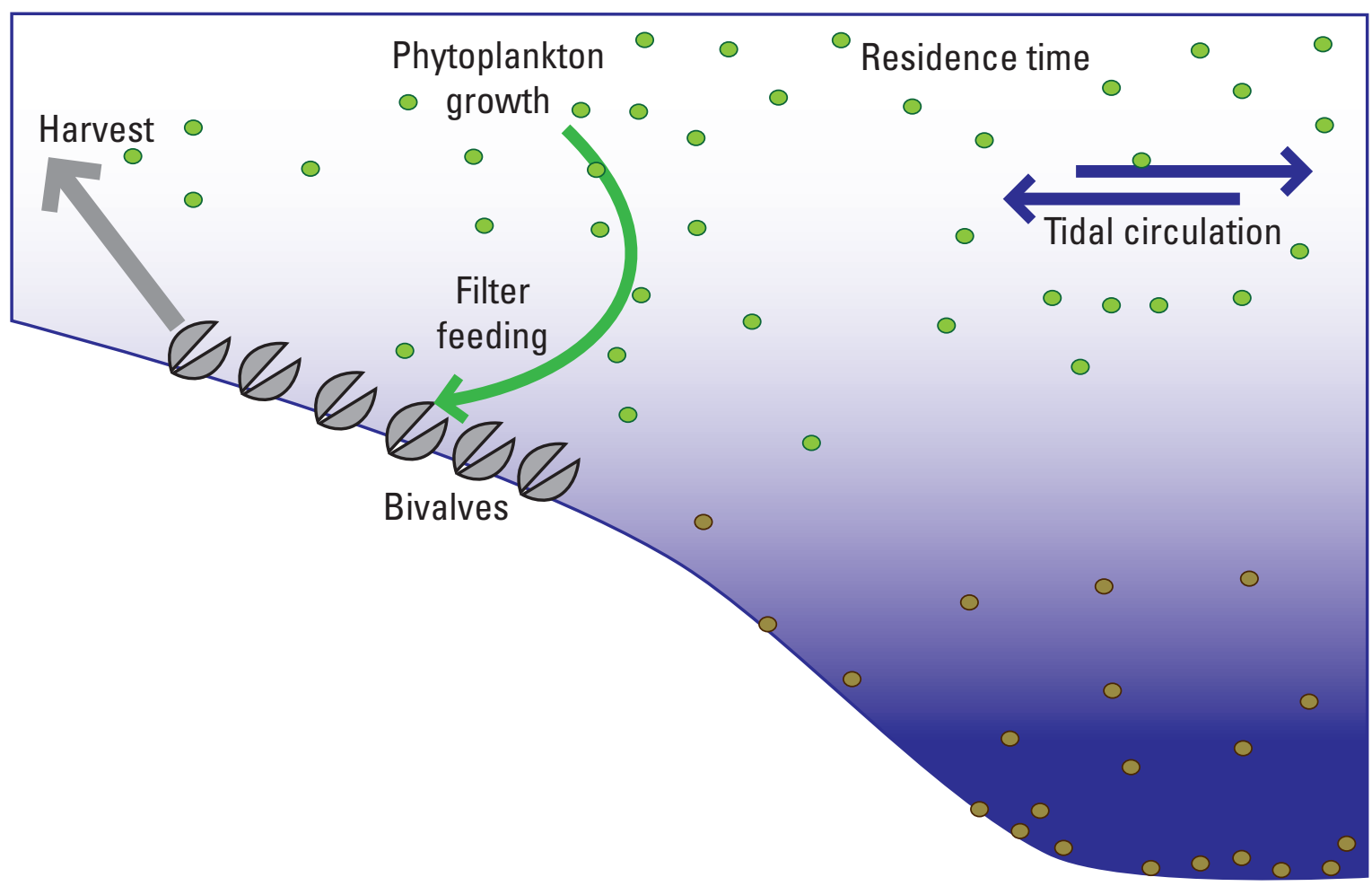

Figure 4. Residence time (which is a function of tidal circulation), phytoplankton growth, and filter feeding constitute fundamental biophysical indicators for assessing the relative importance of filter feeding on phytoplankton. Shading indicates limited light availability for phytoplankton. 
these estimated rates would be imprecise, this approach is computationally simple and can be applied repeatedly using different estimates to assess the sensitivity of the results.

By using the biophysical-indicator approach, it might be possible to identify regions with intermediate residence times where phytoplankton concentrations are likely to be sensitive to changes in shellfish density. Bricker and others (2007) used gross residence times for a national, comparative assessment of eutrophication in estuaries. This approach could be used to identify comparable systems where there may be information about the effectiveness of bivalve filter feeders in controlling phytoplankton biomass. It might be possible to extend the "filtration pressure" indicator developed by Gibbs (2007) to nutrients where, for example, the nutrient content of harvested bivalves is compared to nutrient inputs for a region of Puget Sound. This approach, however, would be indiscriminant regarding the timing or source of nutrients.

Although comparison or graphical analysis of the dominant biophysical processes has been successful for assessing system-scale affects of bivalves on phytoplankton, a comparable approach has not been developed for nutrients because of complex and time-varying transformation and storage processes. Clearance rates are calculated for a specific control volume, time period, and seston constituent and, as a result, do not explicitly account for transformation or changes in storage of that constituent. The effects of nutrient transformations or storage are embedded in measurements.
If those measurements do not account for the various forms of nutrients, or resolve changes in nutrient storage over time, clearance rates are not a complete or accurate basis for quantifying the effects of bivalves. A recent quantitative analysis by zu Ermgassen and others (2013) of Olympia oysters determined that filter feeding capacity generally would have been low for Pacific coast estuaries given historical oyster populations. The zu Ermgassen and others (2013) study, however, did not include Puget Sound.

\section{Approach 4-Extending a Simple Biophysical Model with a Spatial Framework}

A biophysical model that incorporates clearance rates, residence time, and phytoplankton growth rate can be extended with a spatial framework that allows these parameters to vary in different parts of an estuary (fig. 5). In Willapa Bay, Washington, Banas and others (2007) extended the approach of scaling measured clearance rates to an estuary by coupling it to a spatially-explicit circulation model, to account for tidal exchange and mixing within the estuary, and phytoplankton production. The model accounts for the observed longitudinal chlorophyll gradient, but is relatively insensitive to the precise value of the clearance rate even in parts of the estuary with long retention times where filter feeders have the strongest control on chlorophyll

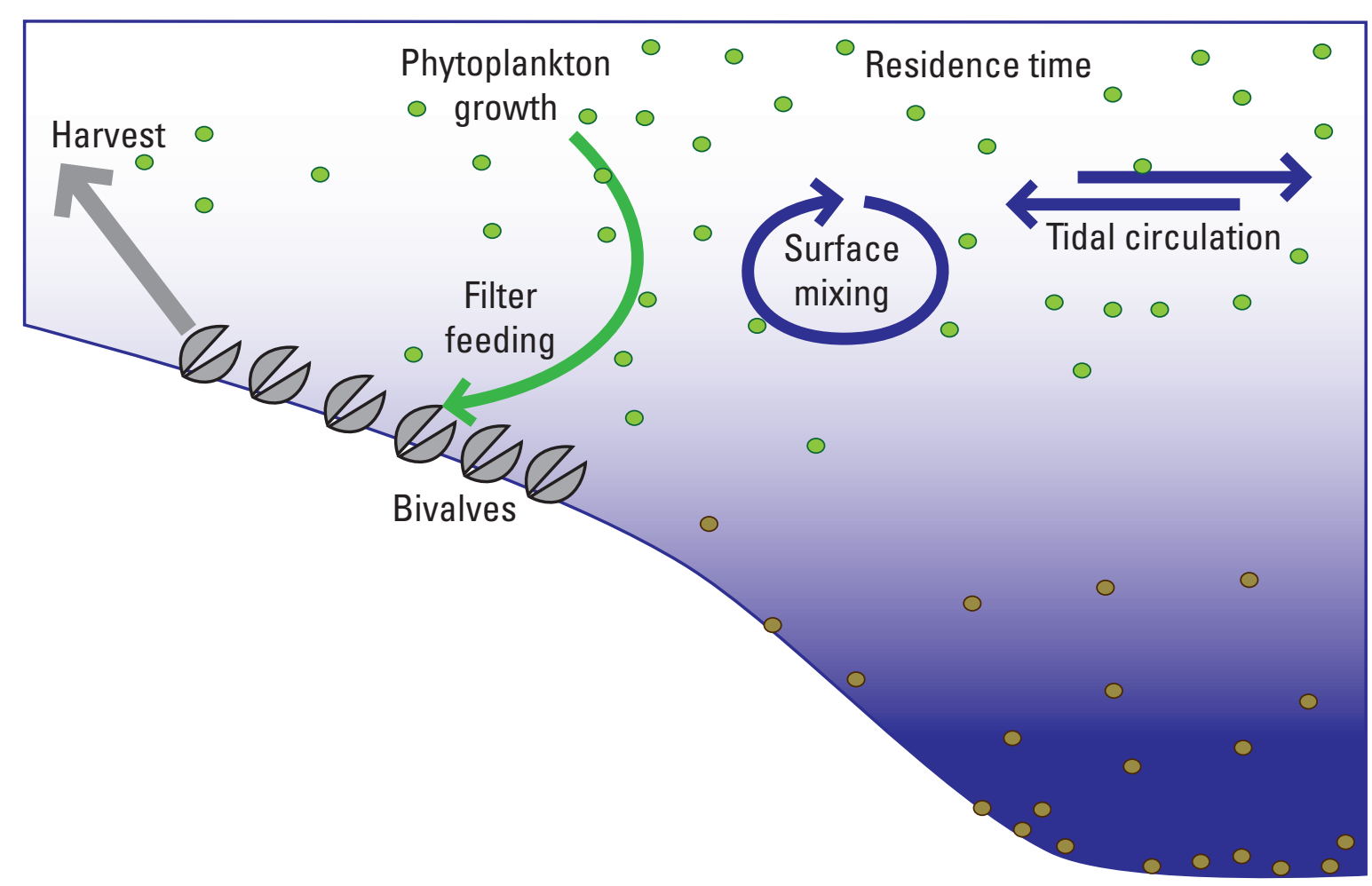

Figure 5. Spatial variation in hydrodynamics, phytoplankton growth, and filter feeding across an estuary can be addressed by using a spatially disaggregated model. Shading indicates limited light availability for phytoplankton. 
concentration. The simulated mass of phytoplankton consumed by filter feeders is not a linear function of their density, which would be represented by a constant clearance rate. Indeed, benthic intake increases only from about 10 to 30 percent of tidal phytoplankton supply, for an order of magnitude change in the clearance rate from about $10^{-5} \mathrm{~m} / \mathrm{s}$ to $10^{-4} \mathrm{~m} / \mathrm{s}$. The decreasing clearance rate with increasing filter feeder density combined with the relatively low fraction of total phytoplankton supply consumed by filter feeders indicates that phytoplankton availability is limited locally through the combination of grazing and the lack of mixing. In the case of Willapa Bay, the variation in residence times across the estuary appears to be the dominant factor controlling phytoplankton concentration.

This approach requires a spatially disaggregated (or spatially explicit) hydrodynamic model to account for tidal exchange of phytoplankton and mixing/retention of water within Puget Sound (see Approach 3: Spatially Aggregated Biophysical Indicators). The model requires parameters representing net production (phytoplankton growth less zooplankton grazing), filter feeder densities and spatial extent, and a clearance rate appropriate for the spatial resolution of the model (an average value for a grid cell or other modeling unit). Output is limited to phytoplankton concentration for a specified set of parameters over tidal cycles. Any interpretation of broader water quality effects would require additional analyses. The model does not explicitly address other biophysical processes that store or transform nutrients. The approach would provide an index of relative effects of filter feeders, which might make some broad assumptions about bivalve clearance rates on a per-biomass basis (constrained by mass-specific measurements in the laboratory and field) and about phytoplankton growth rates (constrained, again, by mass-specific measurements in the laboratory and field). Then, local information about residence time and bivalve biomass could be brought together to map relative clearance rates throughout Puget Sound.

\section{Approach 5-Integrating Biogeochemical Processes into a Lower Trophic Level Model}

Nutrient cycling in estuaries involves multiple pathways (fig. 6), including excretion of nutrients by bivalves (that is, the transformation of phytoplankton into metabolic waste), resuspension of particulate nutrients from pseudofeces and feces, and benthic mineralization/sediment diagenesis of psuedofeces and feces (Prins and others, 1998). Prins and Smaal (1994) estimated that mussels contribute 30 percent of nitrogen mineralization in the Oosterschelde estuary, The Netherlands. Pomeroy and others (2006) identified the proximity of anoxic and oxic sediments (or temporal cycling of these conditions) as a necessary condition for nutrient mineralization. Newell and others (2005) suggested

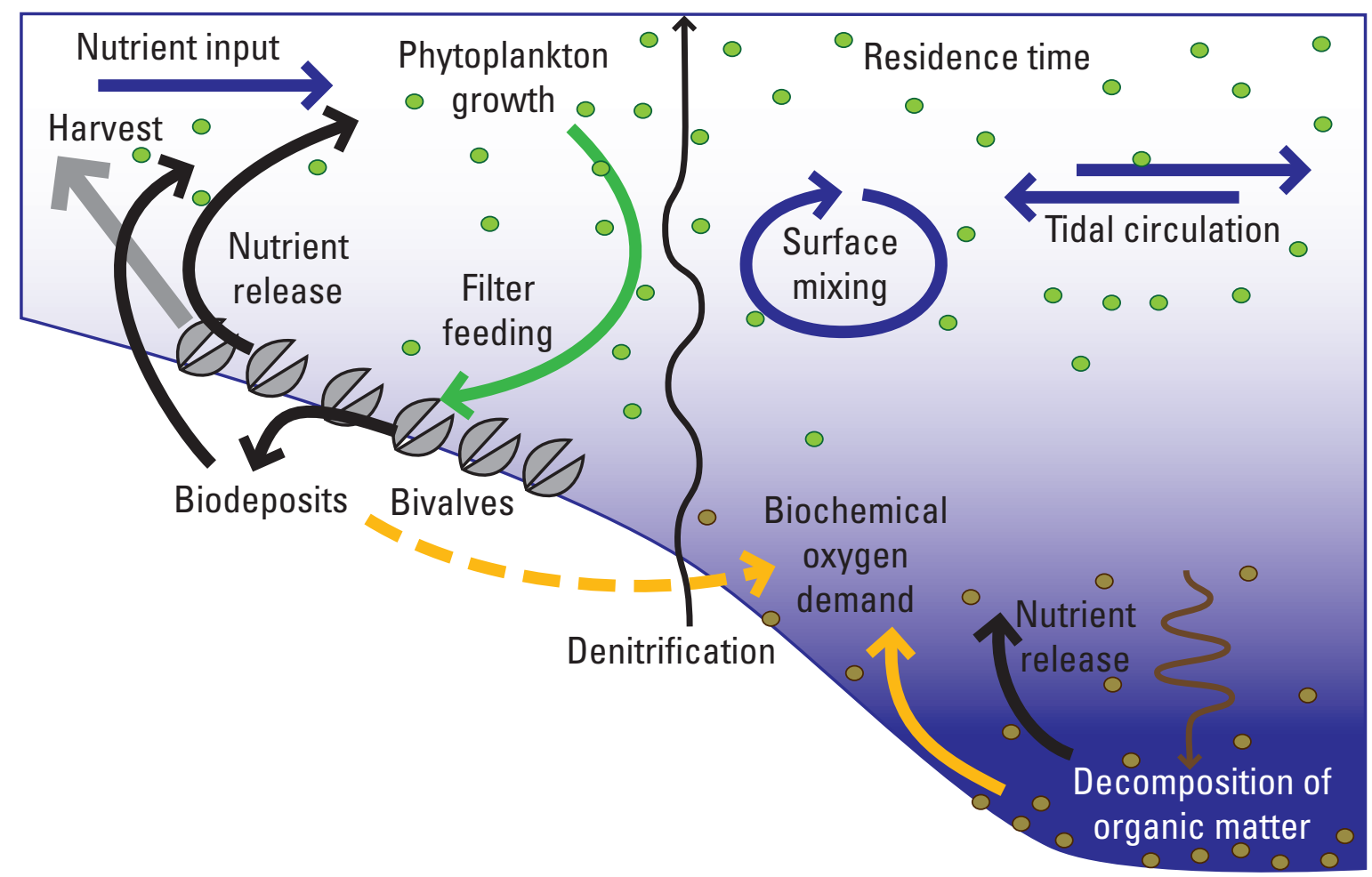

Figure 6. Nutrients released by shellfish and decomposition that contribute to the pool of nutrients in the water column available to phytoplankton. Decomposition also consumes oxygen. Shading indicates limited light availability for phytoplankton. 
that in addition to sediment burial of nutrients and coupled nitrification-denitrification, filter feeders increase in light penetration and, thus, promote benthic primary production and reduce phytoplankton production in the water column. For nutrient management in Puget Sound, transformation, retention, and release of nutrients likely depend on biogeochemical processes that may not be well addressed using a simple approach based on clearance rates.

Cranford and others (2007) modified a "low trophic level" model introduced by Dowd (2005) to analyze the role of mussel aquaculture in nitrogen dynamics in Tracadie Bay, Prince Edward Island, Canada. The spatially aggregated model represents major trophic interactions and biogeochemical processes, including zooplankton grazing, bivalve growth, remineralization of nutrients from particulate organic material, and re-suspension and mineralization of nutrients from sediment. The model used first order kinetics based on benthic and detrital nitrogen pools to account for nitrogen re-mineralization. Cranford and others (2007) also constructed a nitrogen budget for comparison. Their findings include:

- mussel harvest removed less than 10 percent of nitrogen inputs from the Tracadie Bay watershed (harvest of approximately 9 tons $\mathrm{N} / \mathrm{yr}$ compared to inputs of approximately 100 tons $\mathrm{N} / \mathrm{yr}$ );

- mussels ingested 230 ton N/yr with 92 tons directly from phytoplankton, absorbed 76 tons N/yr, and egested 154 tons N/yr;

- nitrogen contributed by mussel urine and biodeposits to the water column is approximately 20 times more than the nitrogen removed in the harvest; and

- mussel biodeposits contribute significantly to the benthic nitrogen pool (approximately 160 tons $\mathrm{N}$ per year) much of which (approximately 100 tons N/yr) returns to the water column through re-suspension or re-mineralization.

In this case, mussels may retain nutrients from terrestrial sources in the estuary, increase the seasonal availability of nutrients in the water column, and as a result promote higher phytoplankton production than if the nutrients had been flushed out of the system by tidal circulation. Tracadie Bay differs from Puget Sound in that there is a net export of nitrogen to the Gulf of St. Lawrence, which would likely increase the relative significance of bivalve filter feeding in nutrient dynamics. There may be embayments in Puget Sound that export nutrients and, thus, function similarly to Tracadie Bay.

Miller and Wands (2009) modified the spatially disaggregated system-wide eutrophication model (SWEM) to Long Island Sound, New York, to account for bivalve filtration of particulate nutrients, algal uptake of dissolved nutrients, decomposition of organic detritus, and sediment diagenesis. SWEM is an integrated hydrodynamic-water-quality model that includes phytoplankton growth and nutrient cycling through primary producers, bivalves, water, and sediments. A constant clearance rate $\left(0.033 \mathrm{~m}^{3} / \mathrm{g}\right.$ bivalve carbon biomass per day) adjusted using an efficiency factor (0.65-0.75) was used to represent bivalve filter feeding. The model was run assuming harvest would maintain shellfish growth rates and, thus, the nutrient assimilation rate corresponding to the assumed clearance rate. Model simulations showed increased DO in response, but the assumed shellfish growth rates require validation.

\section{Approach 6-Spatially Aggregated, Bioenergetics Model with Full Trophic Dynamics}

A bioenergetics model provides an alternative approach that focuses on the trophic dynamics to account for the processing and retention of nutrients in different parts of the food web of an estuary (fig. 7). In an application of a bioenergetics model to Upper South Cover, Nova Scotia, and Marennes-Oleron Bay, France, Grant and Bacher (1998) determined that blue mussel growth rates were sensitive to seston characteristics (carbon content of POM) and particle rejection (also known as feeding efficiency). Fulford and others (2010) constructed a bioenergetics model for Chesapeake Bay that calculates the biomass of different functional groups in the system, and particulate and dissolved nutrients. The estuary community was divided into six producer groups and six consumer groups linked directly through predator-prey relations and indirectly through detritus pools (particulate nutrients) and dissolved nutrients. The model calculates changes in biomass of the different groups at a sub-daily time step, but does not resolve trophic dynamics within the estuary. As a result, parameters must represent average or effective values for the entire system. 
A bioenergetics energetics model requires estimates of energy (or carbon) fluxes between each trophic level in a system: primary production (phytoplankton growth), grazing rates including bivalve filter feeders, predation of grazers (zooplankton and fish), and decomposition. For nutrient management in Puget Sound, the primary issues are whether increased bivalve filter feeding adds to the system-wide grazing rate or simply off-sets other grazers and how an increased flux of energy through bivalves affects decomposition, which is essentially the substitution of biodeposits and urine from shellfish for detritus from dead phytoplankton. Each of these fluxes would need to be estimated before a bioenergetics model could be applied to simulate the net effect on phytoplankton production. Approach 6 would have to be applied to an area of Puget Sound where phytoplankton growth, tidal circulation, and shellfish densities could be approximated with spatially averaged values as with other spatially aggregated models.

\section{Approach 7-Spatially Explicit, Ecosystem Model}

Spatially explicit ecosystem models that represent trophic as well as biophysical dynamics have been used to address conceptual gaps of simpler models. In their most complete form, these models account for circulation of water in an estuary that transports particulate and dissolved materials, biogeochemical processes that transform nutrients and physical properties of water, and trophic dynamics that regulate the availability of particulate and dissolved materials in the system. To address the effects of bivalves on DO concentrations, complex modeling systems must couple hydrodynamics (depth movement of water), water quality (physical properties and dissolved and suspended constituents in the water column including phytoplankton), and filter feeding embedded in trophic webs and biogeochemical cycles. Even a spatially explicit ecosystem model, however, must still use a simplified representation of an estuary. The appropriate type and level of simplification depends on the system and management issues.

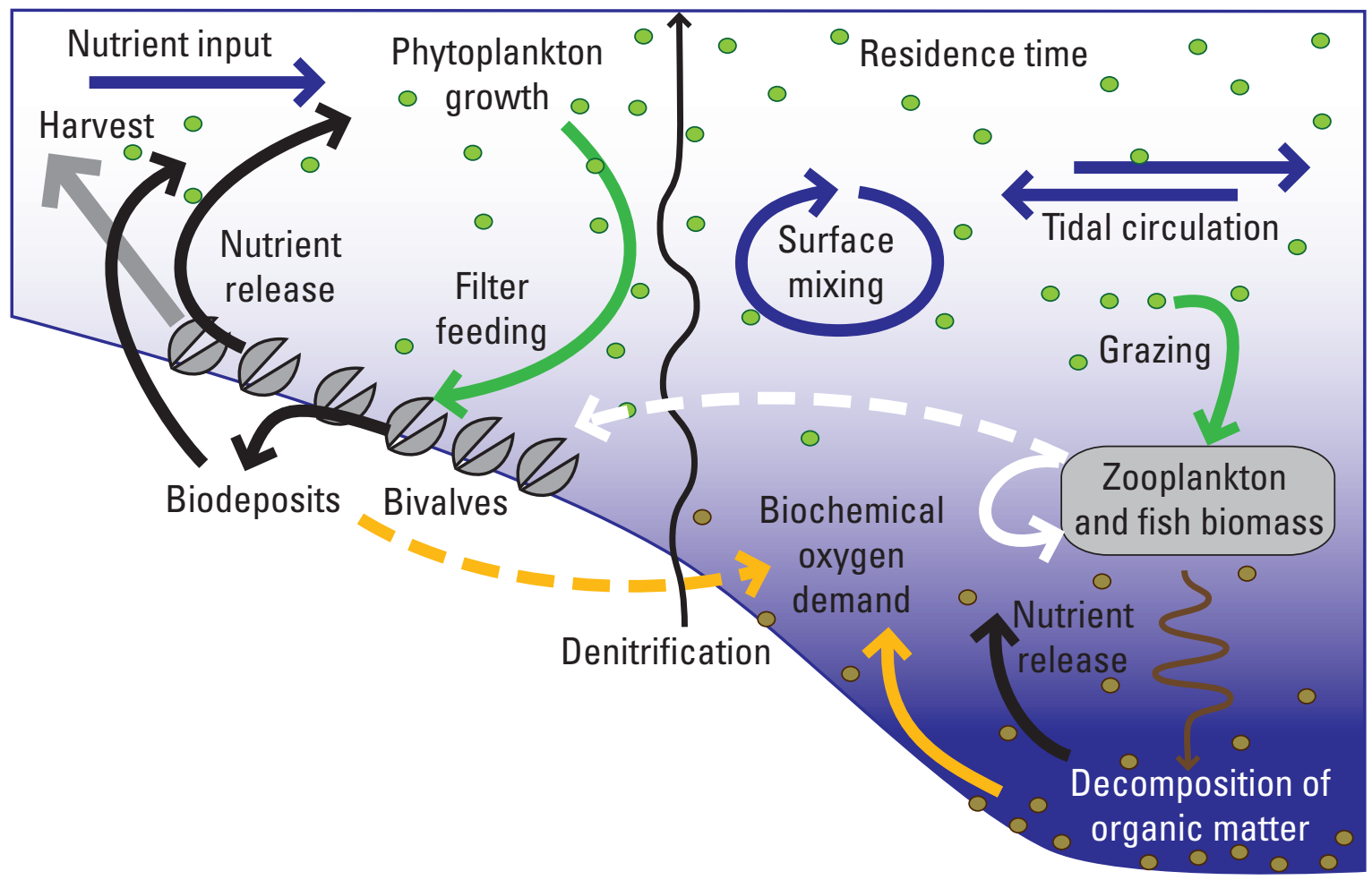

Figure 7. Filter feeders compete with other grazers for phytoplankton and feed on some (zooplankton). Shading indicates limited light availability for phytoplankton. 
Cerco and Noel (2010) linked a watershed hydrology model, a hydrodynamic model, and a water-quality model to form the Chesapeake Bay Environmental Model Package. The water-quality model (CE QUAL ICM) is designed to address eutrophication, and includes zooplankton, benthic feeders, submerged aquatic vegetation, and benthic algae. A sediment diagenesis module was added to support full nutrient cycling. Benthic feeding is represented by a temperature-dependent filtration rate that is limited by seston availability in a local "foraging arena" and adjusted with assimilation efficiency factor. Filtration rates are temperature dependent because of sensitivity demonstrated in a laboratory study (Cerco and Noel, 2007). It was not clear that the experiments evaluated other factors and "the range of filtration rates observed at any temperature indicates the influence of other factors as well" (Cerco and Noel, 2007, p. 333). Cerco and Noel (2010) identified the sensitivity of bivalve effects to residence time, indicating both the importance of simulating residence time accurately and the actual variation in effects that can be anticipated in a large, heterogeneous estuary like Puget Sound.

North and others (2010) developed an alternative modeling system for Chesapeake Bay that uses a coarse resolution hydrodynamic model that represents circulation between two layers of the main channel and tributaries. The hydrodynamic model was linked to water quality, oyster filter feeding, and oyster demographic models. Oyster clearance rates varied with temperature, salinity, and seston concentrations. The model was applied to assess the benefits of various oyster stocking schemes in terms of reduced seston concentration and increased harvest.

Grant and others (2008) coupled a 2-dimensional, finite element circulation model with an ecological model representing mussels, phytoplankton, total nitrogen (ammonia+nitrate), and detrital seston in Tracadie Bay, Prince Edward Island, Canada. Biodeposits were treated as nutrient sinks. The model was calibrated using data collected at different points of the tidal cycle on 1 day in spring and 2 days in summer. Their conclusion was that "farm-scale depletion... cannot simply be extrapolated to seston limitation at the ecosystem level" (Grant and others, 2008, p. 155).

Guyondet and others (2010) demonstrated a spatially explicit model integrating circulation, nutrient cycling including sediment dynamics, and trophic dynamics in the Grande-Entrée Lagoon, Quebec, Canada. They developed a sophisticated representation of the energetic demands of mussel physiology, including reproduction. They concluded that shellfish-nutrient dynamics must account for processes at both local and system scales and confirmed the retention of nutrient by bivalves and their role in accelerating nutrient cycling.
Overall, more complex ecosystem models generally indicate the importance of cross-scale linkages to account for local depletion of phytoplankton by filter feeding, local availability of nutrients in the water column, and large-scale fluxes of nutrients due to circulation and trophic transfers. Of these factors, however, it is not clear that the ratio of nutrients stored to nutrients regenerated is sensitive to nutrient transfers to high trophic levels (for example, pelagic fishes) in Puget Sound.

\section{A Phased Approach for Evaluating Shellfish Effects on Nutrient Dynamics}

Existing approaches provide a wide range of options for evaluating the effects of shellfish on nutrient dynamics in Puget Sound. The overarching rationale for using any approach is whether it informs decisions for managing nutrients. Although no single approach is sufficient for addressing all nutrient issues across Puget Sound and there are considerable information gaps for the more sophisticated models, it would be possible to adopt a phased approach that relies initially on existing information and, then, develops more detailed information in locations where there is a management need. Biophysical indicators (approach 3) could be integrated as a screening tool to identify locations where nutrient dynamics are likely to be sensitive to bivalve filter feeder density. Future studies that better resolve shellfish contributions to the fraction of nutrients sequestered, regenerated, and denitrified could be used to refine the screening level conclusions. In areas where nutrient dynamics are sensitive to shellfish densities and where shellfish are harvested, more detailed analysis of the short-term effects of shellfish on nutrient availability during summer would require additional measurement of nutrient fluxes from shellfish urine and sediments, and rates of biodeposition.

Because of the complexity of nutrient cycling, detailed analysis of the effects of shellfish would require a model that integrates nutrient concentrations in the water column with nutrient fluxes from phytoplankton growth and death, filter feeding and urination by bivalves, and sediment diagenesis (decomposition of biodeposits and organic detritus) (approach 5). Once the response of nutrients to shellfish density can be represented accurately, the results could be used to calibrate parameters in an existing water-quality model (for example, Khangaonkar and others, 2012) or develop additional modules to account for additional nutrient dynamics. 


\section{Factors to Consider in Quantifying the Effects of Shellfish on Nutrients and Associated Gaps for Application to Puget Sound}

Beyond the specific requirements for implementing these approaches, application of any approach requires a fundamental understanding of key biophysical issues in the areas of Puget Sound where the approach will be used. Five issues emerge from the various approaches used in other estuaries. Three of the issues concern estuaries as ecosystems: (1) circulation, (2) nutrient cycling, and (3) trophic dynamics; two more issues primarily concern bivalve feeding: (4) prey preferences and seston composition, and (5) seasonal variability in clearance rates. The significance of these issues in Puget Sound is unknown but should be assessed as part of the development of any approach for quantifying the effects of shellfish on nutrient availability in Puget Sound. Some of these issues might be ignored because they are likely to have little effect on the results. Other issues might be important in Puget Sound and therefore require an approach that incorporates specific processes.

\section{Tidal Circulation}

Tidal circulation transports plankton from the photic zone to bivalves in the benthos, and nutrients into and out of the photic zone from the benthos and marine waters (Dame and Prins, 1998; Banas and others, 2007; Cerco and Noel, 2010; Maar and others, 2010). As such, tidal circulation regulates the effect of bivalves on water column nutrients available to phytoplankton. In estuaries with short residence times, seston concentrations are regulated by source water (marine or fresh), and bivalve filter feeding has little effect on seston concentrations. As residence time increases, filter feeders can reduce seston concentration, provided plankton growth rates are lower than clearance rates. In these cases, increased filter feeding is likely to lower seston concentration, even though nutrient availability may increase, and phytoplankton production may remain stable. In estuaries with long residence time, and where filter feeder populations are close to carrying capacity, increased bivalve densities will not lower seston concentration.

Spatially explicit information on tidal circulation that accounts for residence times of water, and particulate and dissolved fluxes into and out of shellfish beds, is necessary for quantifying the water quality effects of bivalves. Several recent and ongoing studies can be used to characterize circulation at different spatial and temporal scales in Puget Sound. Babson and others (2006) developed an aggregated box model of the Puget Sound circulation covering the region from Admiralty Inlet into Hood Canal, Whidbey Basin, and South Puget Sound (fig. 1). Vertical resolution is limited to two layers. Annual and seasonal patterns are well represented. Khangaonkar and others (2012) and Sutherland and others (2011) have developed circulation models of Puget Sound within larger model domains that extend to the continental shelf. Results could be used to describe regional or local patterns. Within the Puget Sound, Kawase and Bahng (2011) and Roberts and others (2009) have developed circulation models of Hood Canal and South/Central Puget Sound, respectively. Coarse resolution information representing main channels, embayments, and tributaries, for example, may be adequate where residence times are relatively uniform and the water column is well-mixed within those elements (North and others, 2010).

\section{Nutrient Cycling}

Evaluating the effect of bivalves on nutrient availability in an estuary requires an understanding of nutrient dynamics, including retention and cycling (Prins and others, 1998; Grant and others, 2008; Sandwell and others, 2009; Guyondet and others, 2010). Nutrient retention depends on the proximity of shellfish relative to sediment sources (inflow) and tidal mixing (outflow). Bivalves expedite nutrient cycling by rapidly converting nutrients bound in seston to dissolved ammonia that can be used directly by plankton. Nutrient cycling also depends on sediment supporting mineralization of organic nitrogen in pseudofeces and feces, which requires anoxic conditions in proximity to shellfish beds. Although the waterquality model for Puget Sound developed by Khangaonkar and others (2012) accounts for nutrient cycling, between surface and bottom waters, neither the flux of nutrients excreted by bivalves nor the flux of dissolved nutrients from sediments is documented in Puget Sound during periods when hypoxia is likely to occur. Roberts and others (2009) and Kawase and Bahng (2011) simulated nutrient fluxes in Hood Canal and South/Central Puget Sound. No nutrient modeling efforts to date have included shellfish explicitly. Both Khangoankar and others (2012) and ongoing South/Central Puget Sound modeling studies specify sediment fluxes to the water column from general processes that may include shellfish.

Grundmanis and Murray (1977) demonstrated the predominance of denitrification in Puget Sound sediments, but also its coupling to nitrification, so nitrogen cycling and the flux of nitrogen from sediments potentially are potentially important for evaluating the effects of shellfish on nutrient availability. Benthic organisms that burrow into sediments create the conditions required for sediment nitrification (Grundmanis and Murray, 1977). 


\section{Trophic Dynamics}

Bivalves are embedded in estuarine food webs, which regulate bivalve filter feeding through prey availability and respond to their consumption of plankton (Prins and others, 1998; Banas and others, 2007; Cranford and others, 2007; Fulford and others, 2010). The net effect of bivalve filter feeding on phytoplankton biomass cannot be quantified accurately without accounting for associated changes in grazing rates of competitors in estuarine food web, which prompted Fulford and others (2010) to develop a simulation model of trophic dynamics for Chesapeake Bay. The end-member effects of competing filter feeders are (1) any uptake of phytoplankton by bivalves is offset by a reduction in uptake by other filter feeder because bivalves compete directly for a limited food resource, or (2) other filter feeders have no effect on BOD or nutrient cycling because, for example, their fate is the same as phytoplankton, as might be possible in the case of zooplankton. Although a modeling approach such as that used by Fulford and others (2010) could be applied to Puget Sound, the importance of competition among filter feeders to nutrient dynamics in Puget Sound has yet to be established, and should be a prerequisite before embarking on the development of a model to simulate trophic dynamics.

This issue requires an understanding of the major pathways that carbon and nutrients take through food webs in Puget Sound and, in particular, routes that lead to distinctly different biochemical oxygen demand including heterotrophic respiration. The amount of nutrients stored at different trophic levels, and the fluxes between levels, are not documented for Puget Sound, although a trophic-dynamics model developed by Harvey and others (2012) could be used to evaluate whether trophic transfers are large enough to warrant further investigation. Nichols (1975) determined that the deposit-feeding polychaete, Pectinaria californiensis, contributed significantly to trophic dynamics through turnover of organic material in Puget Sound. Estimates of local carrying capacity for filter feeders are essential to determine whether increased filter feeder density will decrease seston particulate concentrations.

\section{Prey Preferences and Seston Composition}

Bivalve filter feeders prey preferentially on certain types and size-classes of seston. Bivalves are particularly inefficient at retaining small particles (for example, less than $5 \mu \mathrm{m}$ ) (Petersen and others, 2004; Ward and Shumway, 2004; Greene and others, 2011). Prins and others (1994) determined that seasonal changes in phytoplankton assemblages were the primary cause of variation in measured clearance rates of mussels from the Wadden Sea, Netherlands. Mussels reduced feeding during a bloom of the haptophycean Phaeocystis sp., but increased feeding during a bloom of the diatom Lepotcylindrus. Cranford and Hill (1999) documented seasonal variation in the organic content of seston from 30 percent (summer) to 90 percent (spring) in Bedford Basin and Mahone Bay, Nova Scotia, Canada. Seston particle concentrations reached $5 \mathrm{mg} / \mathrm{L}$ during spring in Bedford Basin, but remained less than $2 \mathrm{mg} / \mathrm{L}$ in Mahone Bay.

Prey preference of filter feeders can affect plankton assemblage indirectly through trophic webs where, for example, bivalves selectively prey on some members of the assemblage or compete with some members for the same prey. In Chesapeake Bay, Fulford and others (2010) identified size-selective feeding preference of 2 to $50 \mu \mathrm{m}$ as a principal reason, along with the limitation of high grazing rates to spring and summer, for the relatively small simulated effect of oyster on phytoplankton abundance (approximately 1 percent change in phytoplankton biomass for each factor increase in oyster biomass).

The end-member effects of prey-preference in bivalve filter feeding are: (1) bivalve filtering reduces only a small part of the phytoplankton assemblage in Puget Sound, or (2) bivalve filter feeding affects much of the phytoplankton assemblage in Puget Sound. This gap requires an understanding of the size-preference of each type of filter feeder, and the size-distribution of phytoplankton in Puget Sound. Clearance rates determined in laboratories or other estuaries cannot be applied without compensating for differences in the planktonic assemblage (for example, if the planktonic assemblage is dominated by small organisms, then the effective clearance rate for the system may be low relative to clearance rates measured elsewhere). In a recent study, seston concentrations of 3 to $8 \mathrm{mg} / \mathrm{L}$ were measured in Clam Bay and Cypress Island in Puget Sound, of which phytoplankton organics represented less than $0.1-0.9 \mathrm{mg} / \mathrm{L}$ (Rensel and others, 2011).

\section{Seasonal Variability of Clearance Rates and Nutrient Uptake}

Clearance rates and nutrient uptake by bivalves vary seasonally in estuaries and are as large as the variability of measured clearance rates. Cranford and Hill (1999) observed large seasonal variation in filter feeding by mussels (Mytilus edulis) and scallops (Placopecten magellanicus) in Bedford and Mahone Bay, Nova Scotia, Canada. Seston particulate concentrations ranged from less than 1 to $8 \mathrm{mg} / \mathrm{L}$, and temperature varied from 2 to $16^{\circ} \mathrm{C}$. Clearance rates (mean $0.5 \mathrm{~L} / \mathrm{g}$ dry weight/h, range from 0.06 to 1.0 for scallops; mean $0.8 \mathrm{~L} / \mathrm{g}$ dry weight/h, range from 0.1 to 2.1 for mussels) were highest in October and November. The bivalves were able to regulate both clearance rates and absorption efficiency to compensate for changes in food availability/ quality, but also to respond to increased energy demands for reproduction. Dame and others (1989) observed a seasonal shift in ammonium flux from an intertidal oyster reef in Bly Creek, South Carolina, from uptake during winter and spring 
to release during summer and autumn. Oyster densities were 196 g/m (dry soft body biomass). Prins and others (1994) documented seasonal variation in clearance rates of mussels cultured in a tank (density from 1,000 to 2,000 mussels $/ \mathrm{m}^{2}$, 600 to $1,400 \mathrm{~g} / \mathrm{m}^{2}$ ) from 0.4 to 2.7 cubic meters per square meter per hour $\mathrm{m}^{3} / \mathrm{m}^{2} / \mathrm{h}$ (highest rates in August and lowest in January and April-June) that could be attributed to changes in seston composition. Water was pumped from the Wadden Sea, Netherlands and Germany, into the tanks. Seston particulate concentrations ranged from 5 to $17 \mathrm{mg} / \mathrm{L}$. Water temperatures ranged from 5 to $20^{\circ} \mathrm{C}$. Mussels decreased clearance rates during periods of increased food availability and a bloom of Phaeocystis sp. that clogs mussel gills used in filtration. In such cases of algal blooms, "typical" clearance rates would not apply.

Estimates of mean rates of nutrient uptake or uptake during critical periods require an understanding of spatial and temporal variability. Thom and Albright (1990) examined seasonal variation of benthic algae and eelgrass biomass in Seahurst Bight, Puget Sound. Biomass of benthic phytoplankton peaked in April and August, which was likely explained by increasing solar irradiance and decreasing nutrient availability during the spring and summer. Nutrients, except ammonia, exhibited season trends (high in winter, low in late spring-summer). Nitrogen might have been limiting algal biomass in summer. Benhard and Peel (1997) demonstrated nitrogen limitation (ammonia) of phytoplankton during summer in situ nutrient enrichment experiments conducted in Padilla Bay.

\section{Summary}

Various approaches are available for evaluating the effects of filter feeding shellfish on nutrient dynamics in Puget Sound, Washington. Simple approaches such as nutrient budgeting can be easily supported using literature values of nutrient content in shellfish biomass and estimates of harvest, but require a broader framework for evaluating affects on water quality. Moreover, this approach to nutrient budgeting does not resolve seasonal dynamics that are likely important in regulating nutrient availability to phytoplankton during periods of greatest growth. More sophisticated approaches can be used to locate places where bivalve filter feeding is likely to have an effect, given the magnitude of clearance rates relative to tidal circulation and phytoplankton growth. This approach does not, however, account for nutrient cycling and trophic dynamics that provide feedback and limit the reliability of linear extrapolation of measured clearance rates.

The overarching rationale for using any approach is whether it informs decisions for managing nutrients. Given the range of issues that can modulate the effects of bivalve filter feeding on nutrient dynamics and the variety of conditions across Puget Sound, a modeling system that integrates tidal circulation, biogeochemical processes in the water column and sediments, and trophic dynamics is likely the only comprehensive approach for quantifying the effects of bivalve filter feeding on water quality. This approach can be streamlined in places where a small set of processes (for example, circulation and plankton growth) are expected to dominate nutrient dynamics, but even in this case, site-specific information with sufficient temporal resolution are unlikely to be available.

A phased approach could be adopted that relies initially on existing information and, then, develops more detailed information in locations where there is a management need. Biophysical indicators could be integrated to identify locations where nutrient dynamics are likely to be sensitive to bivalve filter feeder density. Measurements of phytoplankton growth and clearance rates could be used to refine the screening level conclusions. In areas where nutrient dynamics are sensitive to shellfish densities and where shellfish are harvested, more detailed analysis of the short-term effects of shellfish on nutrient availability during summer would require additional measurement of nutrient fluxes from shellfish urine and sediments, and rates of biodeposition. Given the likely importance of nutrient fluxes from marine waters and sediments, the local effects of shellfish on nutrients dynamics would have to be integrated with tidal circulation and sediment diagenesis using a modeling approach over larger scales to assess how changes in shellfish populations affect water quality.

Because of the complexity of nutrient cycling, detailed analysis of the effects of shellfish would require a model that integrates nutrient concentrations in the water column with nutrient fluxes from phytoplankton growth and death, filter feeding and urination by bivalves, and sediment diagenesis (decomposition of biodeposits and organic detritus). Once the response of nutrients to shellfish density can be represented accurately, the results could be used to calibrate parameters in an existing water quality model, or develop additional modules to account for additional nutrient dynamics.

\section{Acknowledgments}

This project was funded by the U.S. Environmental Protection Agency under the Puget Sound Ecosystem Restoration and Protection Cooperative Agreement Grant PC-00J20101 with the Washington State Department of Ecology. The contents do not necessarily reflect the view and policies of the U.S. Environmental Protection Agency. 


\section{References Cited}

Alunno-Bruscia, M., Bourles, Y., Maurer, D., Robert, S., Mazurie, J., Gangnery, A., Goulletquer, P., and Pouvreau, S., 2011, A single bio-energetics growth and reproduction model for the oyster Crassostrea gigas in six Atlantic ecosystems: Journal of Sea Research, v. 66, p. 340-348

Babson, A.L., Kawase, M., and MacCready, P., 2006, Seasonal and interannual variability in the circulation of Puget Sound, Washington-A box model study: Atmosphere-Ocean, v. 44, no. 1, p. 29-45.

Banas, N.S., Hickey, B.M., Newton, J.A., and Ruesink, J.L., 2007, Tidal exchange, bivalve graving, and patterns of primary production in Willapa Bay, Washington, USA: Marine Ecology Progress Series, v. 341, p. 123-139.

Bernhard, A.E., and Peele, E.R., 1997, Nitrogen limitation of phytoplankton in a shallow embayment in northern Puget Sound: Estuaries, v. 20, p. 759-769.

Boegman, L., Loewen, M.R., Culver, D.A., Hamblin, P.F., and Charlton, M.N., 2008, Spatial-dynamic modeling of algae biomass in Lake Erie-Relative impacts of Dreissenid mussels and nutrient loads: Journal of Environmental Engineering, v. 134, p. 456-468.

Bricker, S.B., Ferreira, J.G., and Simas, T., 2003, An integrated methodology for assessment of estuarine trophic status: Ecological Modeling, v. 169, p. 39-60.

Bricker, S., Longstaff, B., Dennison, W., Jones, A., Boicourt, K., Wicks, C., and Woerner, J., 2007, Effects of nutrient enrichment in the nation's estuaries-A decade of change: NOAA Coastal Ocean Program Decision Analysis Series No. 26: Silver Spring, Md., National Centers for Coastal Ocean Science, 328 p.

Cerco, C.F., and Noel, M.D., 2007, Can oyster restoration reverse cultural eutrophication in Chesapeake Bay: Estuaries and Coasts, v. 30, p. 331-343.

Cerco, C.F., and Noel, M.D., 2010, Monitoring, modeling, management impacts of bivalve filter feeders in oligohaline and tidal fresh regions of the Chesapeake Bay system: Ecological Modeling, v. 221, p. 1,054-1,064.

Cranford, P.J., and Hill, P.S., 1999, Seasonal variation in food utilization by the suspension-feeding bivalve molluscs Mytilus edulis and Placopecten magellanicus: Marine Ecology Progress Series, v. 190, p. 223-239.

Cranford, P.J., Strain, P.M., Dowd, M., Hargrave, B.T., Grant, J., and Archambault, M.C., 2007, Influences of mussel aquaculture on nitrogen dynamics in a nutrient enriched coastal embayment: Marine Ecology Progress Series, v. 347, p. 61-78.
Dame, R., Bushek, D., Allen, D., Lewitus, A., Edwards, D., Koeplfler, E., and Gregory, L., 2002, Ecosystem response to bivalve density reduction-Management implications: Aquatic Ecology, v. 36, p. 51-65.

Dame, R.F., and Prins, T.C., 1998, Bivalve carrying capacity in coastal ecosystems: Aquatic Ecology, v. 31, p. 409-421.

Dame, R.F., Spurrier, J.D., and Wolaver, T.G., 1989, Carbon, nitrogen, and phosphorus processing by an oyster reef: Marine Ecology Progress Series, v. 54, p. 249-256.

Dowd, M., 2005, A bio-physical coastal ecosystem model for assessing environmental effects of marine bivalve aquaculture: Ecological Modelling, v. 183, p. 323-346.

Dumbauld, B.R., Ruesink, J.L., and Rumrill, S.S., 2009, The ecological role of bivalve shellfish aquaculture in the estuarine environment-A review with application to oyster and clam culture in West Coast (USA) estuaries: Aquaculture, v. 290, p. 196-223.

Ferreira, J.G., Hawkins, A.J.S., and Bricker, S.B., 2007, Management of productivity, environmental effects and profitability of shellfish aquaculture-The Farm Aquaculture Resource Management (FARM) model: Aquaculture, v. 264, p. 160-174.

Fulford, R.S., Breitburg, D.L., Luckenbach, M., and Newell, R.I.E., 2010, Evaluating ecosystem response to oyster restoration and nutrient load reduction with a multispecies bioenergetics model: Ecological Applications, v. 20, p. 915-934.

Gibbs, M.T., 2007, Sustainability performance indicators for suspended bivalve aquaculture activities: Ecological Indicators, v. 7, p. 94-107.

Goldman, J.C., and Caron, D.A., 1985, Experimental studies on omnivorous microflagellate-Implications for grazing and nutrient regeneration in the marine microbial food chain, Deep Sea Research Part A: Oceanographic Research Papers, v. 32, p. 899-915.

Grant, J., and Bacher, C., 1998, Comparative models of mussel bioenergetics and their validation at field culture sites: Journal of Experimental Marine Biology and Ecology, v. 219 , p. $21-44$.

Grant, J., Bacher, C., Cranford, P.J., Guyondet, T., and Carreau, M., 2008, A spatially explicit ecosystem model of seston depletion in dense mussel culture: Journal of Marine Systems, v. 73, p. 155-168.

Greene, V.E., Sullivan, L.J., Thompson, J.K., and Kimmerer, W.J., 2011, Grazing impact of the invasive clam Corbula amerensis on the microplankton assemblage of the northern San Francisco estuary: Marine Ecology Progress Series, v. 431, p. 183-193. 
Grizzle, R.E., Greene, J.K., and Coen, L.D., 2008, Seston removal by natural and constructed intertidal eastern oyster (Crassostrea virginica) reefs-A comparison with previous laboratory studies, and the value of in situ methods: Estuaries and Coasts, v. 31, p. 1,208-1,220.

Grundmanis, V., and Murray, J.W., 1977, Nitrification and denitrification in marine sediments from Puget Sound: Limnology and Oceanography, v. 22, p. 804-813.

Guyondet, T., Roy, S., Koutitonsky, V.G., Grant, J., and Tita, G., 2010, Integrating multiple scales in the carrying capacity assessment of a coastal ecosystem for bivalve aquaculture: Journal of Sea Research, v., 64, p. 341-359.

Harvey, C.J., Williams, G.D., and Levin, P.S., 2012, Food web structure and trophic control in central Puget Sound: Estuaries and Coasts, v. 35, p. 821-838.

Inoue, T. and Yamamuro, M., 2000, Respiration and ingestion rates of the filter-feeding bivalve Musculista senhousiaImplications for water-quality control: Journal of Marine Systems, v. 26, p. 183-192.

Kawase, M., and Bahng, B., 2011, Seasonal variability of circulation and hydrography in Hood Canal, Washington-A numerical model study: Seattle, University of Washington, Hood Canal Dissolved Oxygen Program Integrated Assessment and Modeling Report, Chap. 3.7, 40 p. accessed November 18, 2013, at http:// www.hoodcanal.washington.edu/documents/document. isp?id=2993.

Khangaonkar, T., Sackmann, B., Long, W., Mohamedali, T., and Roberts, M., 2012, Simulation of annual biogeochemical cycles of nutrient balance, phytoplankton bloom(s), and DO in Puget Sound using an unstructured grid model: Ocean Dynamics, v. 62, iss. 9, p. 1,353-1,379, doi:10.1007/s10236-012-0562-4.

Kimmerer, W.J., 2006, Response of anchovies dampens effects of the invasive bivalve Corbula amurensis on the San Francisco Estuary foodweb: Marine Ecology Progress Series, v. 324, p. 207-218.

Long Island Sound Study, 2013, Nutrient bioextraction overview: Long Island Sound Study, accessed November 15, 2013, at http://longislandsoundstudy.net/issues-actions/ water-quality/nutrient-bioextraction-overview/.

Maar, M.K., Timmermann, K., Petersen, J.K., Gustafsson, K.E., and Storm, L.M., 2010, A model study of the regulation of blue mussels by nutrient loadings and water column stability in a shallow estuary, the Limfjorden: Journal of Sea Research, v. 64, p. 322-333.
Miller, R.E.L., and Wands, J.R., 2009, Applying the system wide eutrophication model (SWEM) for a preliminary quantitative evaluation of biomass harvesting as a nutrient control strategy for Long Island Sound: Mahwah, N.J., technical report submitted to Long Island Sound Study on December 4, 2009, by Hydroqual Incorporated, 50 p., accessed on November 18, 2013, at http:// longislandsoundstudy.net/wp-content/uploads/2010/06/ SWEMbiohrvstrprtv2 $12 \quad 04$ 09.pdf.

Newell, R.I.E., Fisher, T.R., Holyoke, R.R., and Cornwell, J.C., 2005, Influence of eastern oysters on nitrogen and phosphorus regeneration in Chesapeake Bay, USA, in Dame, R., Olenin, S., eds., The comparative roles of suspension feeders in ecosystems: Netherlands, Springer, NATO Series IV - Earth and Environmental Sciences, v. 47, p. 93-120.

Nichols, F.H., 1975, Dynamics and energetics of three depositfeeding benthic invertebrate populations in Puget Sound, Washington: Ecological Monographs, v. 45, p. 57-82.

North, E.W., King, D.M., Xu, J., Hood, R.R., Newell, R.I.E., Paynter, K., Kellogg, M.L., Liddel, M.K., and Boesch, D.F., 2010, Linking optimization and ecological models in a decision support tool for oyster restoration and management: Ecological Applications, v. 20, p. 851-866.

Pacific Shellfish Institute, 2013, Shellfish carrying capacity: Pacific Shellfish Institute, accessed on November 18, 2013, at http://www.pacshell.org/carrying-capacity.asp.

Petersen, J.K., Bougrier, S., Smaal, A.C., Garen, P., Robert, S., Larsen, J.E.N., and Brummelhuis, E., 2004, Intercalibration of mussel Mytilus edulis clearance rate measurements: Marine Ecology Progress Series, v. 267, p. 187-194.

Pomeroy, L.R., D'Elia, C.F., and Schaffner, L.C., 2006, Limits to top-down control of phytoplankton by oysters in Chesapeake Bay: Marine Ecology Progress Series, v. 325, p. 301-309.

Powell, E.N., Hofmann, E.E., Klinck, J.M., and Ray, S.M., 1992, Modeling oyster populations-A commentary on filtration rate-Is faster always better?: Journal of Shellfish Research, v. 11, p. 387-398.

Prins, T.C., Dankers, N., and Smaal, A.C., 1994, Seasonal variation in the filtration rates of a semi-natural mussel bed in relation to seston composition: Journal of Experimental Marine Biology and Ecology, v. 176, p. 69-86.

Prins, T.C., and Smaal, A.C., 1994, The role of blue mussel Mytilus edulic in the cycling of nutrients in the Oosterschelde estuary (The Netherlands): Hydrobiologia, v. 282-283, p. 413-429. 
Prins, T.C., Smaal, A.C., and Dame, R.F., 1998, A review of the feedbacks between bivalve grazing and ecosystem process: Aquatic Ecology, v. 31, p. 349-359.

Roberts, M., Albertson, S., Ahmed, A., and Pelletier, G., 2009, South Puget Sound dissolved oxygen study - South and Central Puget Sound water circulation model development and calibration-External Review DRAFT 10/10/13: Washington State Department of Ecology Publication, 152 p., accessed November 18, 2013, at http://www.ecy. wa.gov/puget_sound/docs/SPSWQrpt externalreview draft 20131011.pdf.

Rensel, J., Bright, K., and Siegrist, Z., 2011, Integrated fish-shellfish mariculture in Puget Sound: National Oceanic and Atmospheric Association, NOAA-Award NA08OAR4170860 Final Report, 82 p., accessed September 10, 2013, at http://www.aquamodel.net/ Downloads/Puget $\% 20$ Sound $\% 20$ IMTA $\% 20$ final $\% 20$ report\%2031May2011.pdf.

Rose, J.M., Tedesco, M., Wikfors, G.H., and Yarish, C., 2010, International workshop on bioextractive technologies for nutrient remediation summary report: Woods Hole, Mass., National Marine Fisheries Service, Northeast Fisheries Science Center Reference Document 10-19,12 p.

Safi, K.A., Hewitt, J.E., and Talman, S.G., 2000, The effect of high inorganic seston loads on prey selection by the suspension-feeding bivalve, Atrina zelandica: Journal of Experimental Marine Biology and Ecology, v. 344, p. 136-148.

Sandwell, D.R., Pilditch, C.A., and Lohrer, A.M., 2009, Density dependent effects of an infaunal suspensionfeeding bivalve (Austrovenus stutchburyi) on sandflat nutrient fluxes and microphyobenthic productivity: Journal of Experimental Marine Biology and Ecology, v. 373, p. 16-25.

Smaal, A., van Stralen, M., and Schuiling, E., 2001, The interaction between shellfish culture and ecosystem processes: Canadian Journal of Fisheries and Aquatic Sciences, v. 58, p. 991-1,002.

Steinberg, P., and Hampden, J., 2010, Nitrogen removal with shellfish harvest in Oakland Bay and Puget Sound, memorandum to Dan Cheney and others: Herrera Environmental Consultants, 10 p., plus appendix., accessed on November 20, 2013, at http://www.pacshell.org/pdf/ NitrogenCyclingReport.pdf.
Strayer, D.L., Caraco, N.F., Cole, J.J., Findlay, S., and Pace, M.L., 1999, Transformation of freshwater ecosystems by bivalves: Bioscience, v. 49, p. 19-27.

Sutherland, D.A., MacCready, P., Banas, N.S., and Smedstad, L., 2011, A model study of the Salish Sea estuarine circulation: Journal of Physical Oceanography, http://dx.doi. org/10.1175/2011JPO4540.1.

Thom, R.M., and Albright, R.G., 1990, Dynamics of benthic vegetation standing-stock, irradiance, and water properties in central Puget Sound: Marine Biology, v. 104, p. 129-141.

Ward, J.W., and Shumway, S.E., 2004, Separating the grain from the chaff-Particle selection in suspension- and deposit-feeding bivalves: Journal of Experimental Marine Biology and Ecology, v. 300, p. 83-130.

Winter, D.F., Banse, K., and Anderson, G.C., 1975, The dynamics of phytoplankton blooms in Puget Sound, a fjord in the northwestern United States: Marine Biology, v. 29, p. 139-176.

Woods Hole Group, 2012, Shellfish propagation demonstration project, technical memorandum II- Program planning estimates and discussion of findings: East Falmouth, Mass., submitted on November 2012 to Town of Falmouth by Woods Hole Group Inc., 35 p., accessed November 18, 2013, at http://www.falmouthmass.us/waterq/technical\%20 memo\%20ii_\%20draft_1.2.13docx.pdf.

York, J.K., Costas, B.A., and McManus, G.B., 2011, Microzooplankton grazing in green water-Results from two contrasting estuaries: Estuaries and Coasts, v. 34, iss. 2, p. 373-385.

zu Ermgassen, P.S.E., Gray, M.W., Langdon, C.J., Spaulding, M.D., and Brumbaugh, R.D., 2013, Quantifying the historic contribution of Olympia oysters to filtration in Pacific Coast (USA) estuaries and the implication for restoration objectives: Aquatic Ecology, v. 47, p. 419-161. 
Publishing support provided by the U.S. Geological Survey

Publishing Network, Tacoma Publishing Service Center

For more information concerning the research in this report, contact the Director, Washington Water Science Center

U.S. Geological Survey

934 Broadway, Suite 300

Tacoma, Washington 98402

http://wa.water.usgs.gov 


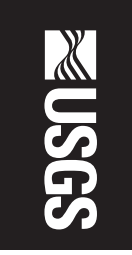

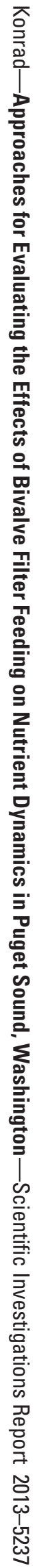

